\title{
New particle growth and shrinkage observed in subtropical environments
}

\author{
L.-H. Young ${ }^{1}$, S.-H. Lee ${ }^{2}$, V. P. Kanawade, ${ }^{2, *}$, T.-C. Hsiao ${ }^{3}$, Y. L. Lee ${ }^{4}$, B.-F. Hwang ${ }^{1}$, Y.-J. Liou ${ }^{1}$, H.-T. Hsu ${ }^{5}$, and \\ P.-J. Tsai ${ }^{1}$ \\ ${ }^{1}$ Department of Occupational Safety and Health, China Medical University, 91 Hsueh-Shih Road, Taichung 40402, \\ Taiwan, Republic of China \\ ${ }^{2}$ College of Public Health, Kent State University, 750 Hilltop Drive, Kent, OH 44240, USA \\ ${ }^{3}$ Graduate Institute of Environmental Engineering, National Central University, 300 Jhongda Road, Jhongli City, \\ Taoyuan County 32001, Taiwan, Republic of China \\ ${ }^{4}$ Graduate Institute of Epidemiology and Preventive Medicine, National Taiwan University, 17 Xu-Zhou Road, Taipei 10020, \\ Taiwan, Republic of China \\ ${ }^{5}$ Department of Health Risk Management, China Medical University, 91 Hsueh-Shih Road, Taichung 40402, Taiwan, \\ Republic of China \\ * currently at: Center for Environmental Science and Engineering, Department of Civil Engineering, Indian Institute of \\ Technology, Kanpur-208016, Uttar Pradesh, India
}

Correspondence to: L.-H. Young (lhy@mail.cmu.edu.tw)

Received: 8 July 2012 - Published in Atmos. Chem. Phys. Discuss.: 30 July 2012

Revised: 24 December 2012 - Accepted: 3 January 2013 - Published: 16 January 2013

\begin{abstract}
We present the first systematic analysis for new particle formation (NPF), growth and shrinkage of new particles at four different sites in subtropical central Taiwan. A total of 14 NPF events were identified from 137 days of ambient measurements during a cold and warm season. The measured formation rates of $10 \mathrm{~nm}$ particles $\left(J_{10}\right)$ and growth rates were in the range of $4.4-30 \mathrm{~cm}^{-3} \mathrm{~s}^{-1}$ and 7.4$24 \mathrm{~nm} \mathrm{~h}^{-1}$, respectively. The onset of NPF events coincided with decreases of condensation sink (CS) and increases of $\mathrm{SO}_{2}$ under enhanced atmospheric mixing and dilution. However, the lower or comparable $\mathrm{SO}_{2}$ on event days than on non-event days suggests that $\mathrm{SO}_{2}$ was not a limiting factor for NPF. On non-event days, the particle number concentrations were mostly driven by traffic emissions. We also observed shrinkage of new particles, the reversal of growth, during five out of the identified secondary formation. UFP particles events. In intense cases, the grown particles shrank back to the smallest measurable size of $\sim 10 \mathrm{~nm}$, thereby creating a unique "arch-like" shape in the size distribution contour plot. The particle shrinkage rates ranged from -5.1 to $-7.6 \mathrm{~nm} \mathrm{~h}^{-1}$. The corresponding particle volume losses suggest that a notable fraction of the condensable species that
\end{abstract}

contributed to growth was semi-volatile. The particle shrinkage was related to enhanced atmospheric dilution, high ambient temperature and low relative humidity, thus favoring the evaporation of semi-volatile species from the particulate phase to the gas phase. Our observations show that the new particle growth could be a reversible process, in which the evaporating semi-volatile species are important for the growth of new particles to sizes of environmental health concerns.

\section{Introduction}

Atmospheric aerosols impact various aspects of human health, air quality and climate. Aerosol particles are also linked to short- and long-term cardiovascular disease and mortality (Atkinson et al., 2010; Pope et al., 2009). Fine particles of diameters smaller than 2.5 micrometer can be more pertinent to health effects (Peng et al., 2009; Zanobetti and Schwartz, 2009). And, ultrafine particles (UFPs) in the size range of smaller than $100 \mathrm{~nm}$ can be even more toxic, as they deposit more efficiently in the alveolar region than larger 
particles (Nel, 2006). In ambient air, aerosol number concentrations are dominated by these UFPs.

Atmospheric UFPs are from two source processes, primary emissions and secondary formation. Primary UFP particles are directly emitted from motor vehicles, particularly heavy-duty diesel engines (Morawska et al., 2008). For example, emission studies of heavy-duty diesel engines have shown that non-volatile UFPs emitted from the exhaust are on the order of $10^{7}-10^{8} \mathrm{~cm}^{-3}$ (Heikkilä et al., 2009; Young et al., 2012), several orders of magnitude higher than ambient UFP concentrations. The secondary formation process that governs particle number concentrations is new particle formation (NPF). NPF involves nucleation (gas to particle conversion) and initial growth to sizes of $1-3 \mathrm{~nm}$ detectable by current instruments (Kulmala et al., 2012; Vanhanen et al., 2011). Once clusters formed via nucleation and become larger than the critical size, growth becomes spontaneous. Subsequent growth of freshly nucleated particles often persists for many hours under favorable atmospheric conditions (e.g., under low pre-existing aerosol particle and high concentrations of low volatility compounds) to become larger than $\sim 50 \mathrm{~nm}$ and could act as cloud condensation nuclei (Dusek et al., 2006). Unlike motor vehicle emissions that are limited to urban areas, NPF events have been observed in all types of environments, including rural, coastal, urban areas and boreal forest (Kulmala et al., 2004). More recently, Hallar et al. (2011) showed frequent NPF, correlated with UV irradiance, in background free tropospheric air. Studies have shown that the number concentrations of freshly nucleated particles at the start of NPF typically are in the range of $10^{3}-10^{4} \mathrm{~cm}^{-3}$, but under certain conditions, for example in $\mathrm{SO}_{2}$-enriched plumes and coastal areas, they can be higher than $10^{4} \mathrm{~cm}^{-3}$ (Kulmala et al., 2004; Holmes, 2007; Bzdek and Johnston, 2010). Its spatial scale in regional events can extend beyond tens and up to several hundred kilometers (Stanier et al., 2004; Salma et al., 2011). The large scale of NPF have been recognized as a potentially significant contributor to the global CCN production (Merikanto et al., 2009). Most NPF observations have so far been made at midand high-latitude regions of Northern Hemisphere (Kulmala et al., 2004) and the measurements in subtropical and tropical regions are sparse.

The favorable conditions and mechanisms leading to NPF and growth have been proposed for various atmospheric conditions. Kulmala et al. (2004), Bzdek and Johnston (2010), Hegg and Baker (2009), Holmes (2007), and Kulmala and Kerminen (2008) have illustrated the dynamic relationships among the nucleating (condensable) vapors, pre-existing aerosol densities, particle growth rates and nucleation rates. These studies also showed that NPF occurs when there are excess condensable vapors for the freshly nucleated particles to grow large without being scavenged by pre-existing aerosols. Zhang et al. (2012) reviewed recent advances in nucleation and growth and provided insights of these processes at the molecular level. Due to its low volatility at typical at- mospheric temperatures, gas-phase sulfuric acid $\left(\mathrm{H}_{2} \mathrm{SO}_{4}\right)$ is the most important nucleating vapor (Kuang et al., 2008; Kerminen et al., 2010; Sipila et al., 2010). Ternary species such as ammonia $\left(\mathrm{NH}_{3}\right)$, amines and other organic compounds can also enhance the nucleation rate by stabilizing the critical clusters (Benson et al., 2011; Erupe et al., 2011; Yu et al., 2012; Zhang et al., 2004).

Growth of new particles is governed by coagulation, condensation of low volatility and semi-volatile vapors, and heterogeneous reactions. Coagulation of freshly nucleated particles decreases the particle number and increases the modal size. However, its effect on particle growth is less importance unless the number concentration and nucleation rate exceeds $\sim 10^{5} \mathrm{~cm}^{-3}$ and $10^{4} \mathrm{~cm}^{-3} \mathrm{~s}^{-1}$, respectively (Anttila et al., 2010; Lehtinen et al., 2007). And, such conditions are rather uncommon but have been observed in polluted urban air, engine exhaust, industrial plumes or coastal areas. Yue et al. (2010) showed that intra- and extra-modal coagulation contributed $34 \pm 17 \%$ to particle growth during events with formation rates of $2-13 \mathrm{~cm}^{-3} \mathrm{~s}^{-1}$ in Beijing. Because condensation growth is strongly suppressed owing to the Kelvin effect for small particles, only vapors of low vapor pressure contribute to growth of freshly nucleated particles. Condensation of $\mathrm{H}_{2} \mathrm{SO}_{4}$ and subsequent stabilization by $\mathrm{H}_{2} \mathrm{O}$ is considered irreversible under typical atmospheric conditions, whereas $\mathrm{NH}_{3}$ plays a negligible role in nanoparticle growth (Zhang et al., 2009). However, field studies have found that $\mathrm{H}_{2} \mathrm{SO}_{4}$ condensation alone often fails to fully account for the observed particle growth (Stolzenburg et al., 2005; Yue et al., 2010), and it is possible that other semi-volatile organic vapors contribute to growth of new particles (Laaksonen et al., 2008; Zhang et al., 2009; Riipinen et al., 2011; Pierce et al., 2012). The Kelvin-effect barrier can be overcome by heterogeneous reactions, which can facilitate subsequent condensation of organic vapors (Zhang and Wexler, 2002). Also, amines and particulate-phase $\mathrm{H}_{2} \mathrm{SO}_{4}$ or organic acids lead to the formation of low volatility aminium salts that contribute to particle growth (Smith et al., 2010; Zhang et al., 2012).

Particle shrinkage can also occur due to evaporation of condensed species if the condensation or chemical reactions involved in particle growth are reversible. Suggested reversible processes with regard to new particle growth include the formation of aldol products and glyoxal oligomers in $\mathrm{H}_{2} \mathrm{SO}_{4}$ particles, and the physical adsorption of alcohols by $\mathrm{H}_{2} \mathrm{SO}_{4}$ solution (Zhang et al., 2012). In addition, particlephase oxidation may result in enhanced volatilization of organic aerosols (Kroll et al., 2006; Molina, 2004). Modeling studies showed that vehicle-emitted particles smaller than $40 \mathrm{~nm}$ can shrink when the gas-phase concentration decreases upon dilution (Zhang and Wexler, 2004; Jacobson et al., 2005). In Hong Kong urban air, Yao et al. (2010) observed particle shrinkage following several NPF events and suggested that the particle shrinkage was related to the evaporation of organic components and ammonium nitrate. Recently, Backman et al. (2012) reported similar observations 
in São Paulo, Brazil, and suggested that the decrease of vapor concentrations by changes in atmospheric conditions could occur more rapidly than the decrease of vapor pressure by photochemical oxidation. Therefore, the net effect is the evaporation of the condensed phase to the gas phase.

Previously, Young et al. (2012) have characterized the spatiotemporal variability of $10-1000 \mathrm{~nm}$ submicrometer particles in various subtropical environments (urban, coastal, mountain and downwind) in Taiwan. They found that the variability of particle number is largely driven by primary emissions of local traffic and, to as lesser extent, by secondary NPF. Unlike the primary pathway, the secondary NPF is oftentimes accompanied with intense new particle growth over extended period of time. This NPF and growth are crucial processes for atmospheric aerosols because they can cause the new particles to grow to larger sizes of environmental health implications. With that in mind and building upon our previous work, here we aim to characterize the aerosol kinetics and properties during NPF and growth events and, along with meteorological conditions, to identify favorable conditions leading to those events. Also presented are several notable observations of new particle shrinkage following their prior formation and growth.

\section{Experimental}

\subsection{Observation sites}

The observation sites, instruments, meteorological conditions and data reduction methods are described in detail by Young et al. (2012). Observations were made at four air quality monitoring sites in the central Taiwan, a subtropical island country situated on the western edge of the Pacific Ocean and off the southeastern coast of mainland China. The sites are located 20-50 km apart in the Central Taiwan Air Quality Management District (CTAQMD) of $\sim 7400 \mathrm{~km}^{2}$ and nominally represent urban, coastal, mountain and downwind area (Fig. 1).

The urban site is in the center of the Taichung City basin, which has approximately 2610000 registered vehicles, ranking the 3rd in the country (Taiwan Ministry of Transportation and Communications, http://www.motc.gov. tw/). Among these vehicles, $65 \%$ are 4-stroke and 2-stroke scooters (ratio $=7: 3$ ), $30 \%$ are mostly gasoline-powered passenger cars, and the remaining $5 \%$ are trucks, buses and other types of vehicles. The coastal site is situated $4.8 \mathrm{~km}$ to the western coastline of Taiwan and $9 \mathrm{~km}$ south to the largest coal-fired power plant in Taiwan, which is also the world largest $\mathrm{CO}_{2}$ emitting power plant (http://carma.org). Its annual emission of $\mathrm{SO}_{2}$ and $\mathrm{NO}_{\mathrm{x}}$ in 2010 was 11,564 and 19,143 tons, respectively (http://www.epb.taichung.gov.tw/). The mountain site is located in a relatively rural basin; its east is the Central Mountain Ranges of height $2-3 \mathrm{~km}$. The downwind site is near the southern border of the CTAQMD,

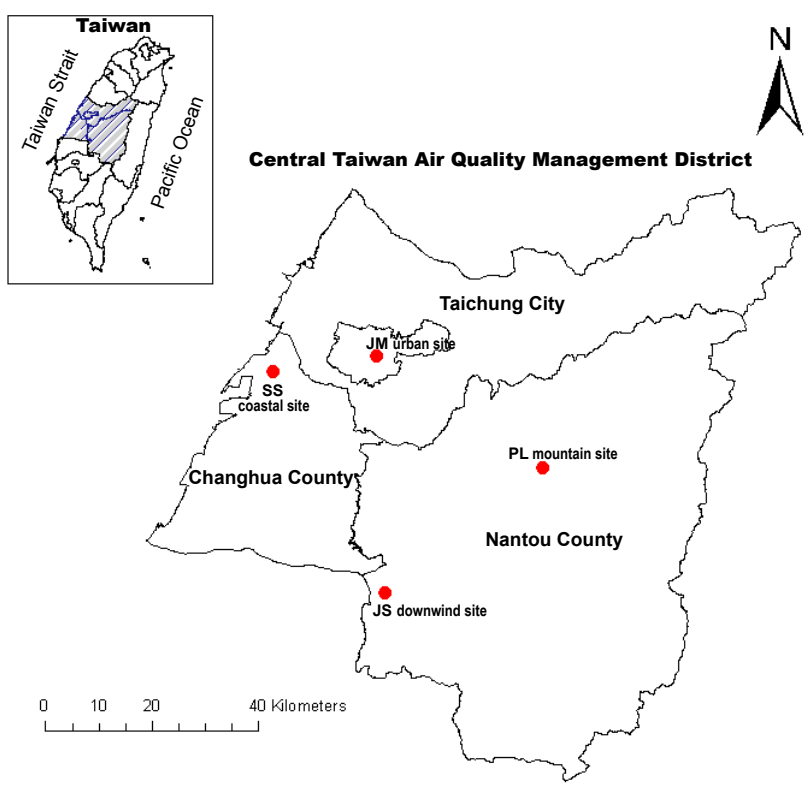

Fig. 1. Map of the four observation sites in the Central Taiwan Air Quality Management District.

$44 \mathrm{~km}$ to the southeast of the Taichung urban area. The prevailing northeasterly winds during winter months were conducive for transport of air pollutants from the upwind urban area to the downwind site.

The sampling campaigns were conducted consecutively at these four sites from October 2008 to January 2009 (cold season) and from August 2010 to October 2010 (warm season). The major meteorological differences between the cold and warm season include the average ambient temperature (20.6 vs. $27.6^{\circ} \mathrm{C}$ ), prevailing wind direction (NNW vs. W) and accumulated precipitation $(57.4$ vs. $283.6 \mathrm{~mm})$. The air quality was considered poorer during the cold season than the warm season, especially the all-sites hourly-average particulate matter larger than 10 micrometer $\left(\mathrm{PM}_{10}, 57.1 \mu \mathrm{g} \mathrm{m}^{-3}\right.$ during the warm season vs. $37.0 \mu^{-3} \mathrm{~m}^{-3}$ during the cold season), particulate matter larger than 2.5 micrometer $\left(\mathrm{PM}_{2.5}\right.$, 37.2 vs. $\left.24.2 \mu \mathrm{g} \mathrm{m}^{-3}\right), \mathrm{NO}_{\mathrm{x}}(23.9$ vs. $15.4 \mathrm{ppb})$ and $\mathrm{SO}_{2}(3.8$ vs. $2.9 \mathrm{ppb}$ ). During the entire study period, we collected a total 26075 aerosol number-size distributions over 137 effective sampling days (with the data coverage of $\sim 92.5 \%$ ).

\subsection{Sampling and instrumentation}

The aerosol measurement systems at all four observation sites were nearly identical and housed inside air-conditioned trailers. Ambient air was drawn through the site rooftop with a flow rate of $8 \mathrm{~L} \mathrm{~min}^{-1}(\mathrm{lpm})$ via a $3-\mathrm{m}$ vertical glass tube (ID $=2 \mathrm{~cm}$, outside diameter $\mathrm{OD}=2.54 \mathrm{~cm}$ ). The outdoor section of the glass tube $(2.5 \mathrm{~m}$ long) was shielded inside an aluminum tube. A short stainless steel forward-facing sampling probe was inserted into the indoor section of the 
remaining glass tube $(0.5 \mathrm{~m})$. A small portion of the sample air $(0.3 \mathrm{lpm})$ was then taken into the scanning mobility particle sizer (SMPS) through the sampling probe with a conductive tubing of $1.5-\mathrm{m}$ maximum length. The diffusion loss to the glass and conductive tubing was estimated to be $15 \%$ for the smallest measureable particles of $11.1 \mathrm{~nm}$ and $6 \%$ for $25 \mathrm{~nm}$ particles, based on Baron and Willeke (2001). However, no loss corrections were made to the measured data because these transport losses were relatively small compared to the temporal variability of $59-195 \%$ for the $10-25 \mathrm{~nm}$ particle number concentrations (Young et al., 2012). The air conditioners inside the trailers were activated only when the indoor temperature exceeded $31^{\circ} \mathrm{C}$. As a result, the sample air temperature basically followed the ambient air temperature. There were no water condensation issues with the sampling tube.

The particle number size distributions were measured with SMPS (GRIMM Aerosol Technik, Gmbh, Germany, Model 5.500) (e.g., Heim et al., 2004). The SMPS consists of an Am-241 neutralizer (Model 5.522), a long Vienna-type differential mobility analyzer (L-DMA; Model 55-900) and a butanol-based condensation particle counter (CPC; Model 5.403). With the default set up, the inner electrode of the LDMA is positively charged. The CPC has a $50 \%$ counting efficiency for particles as small as $4.5 \mathrm{~nm}$, with the saturator and condenser temperature set at $40^{\circ} \mathrm{C}$ and $15^{\circ} \mathrm{C}$, respectively. The SMPS was set to down-scan $6 \mathrm{~min}$ and $26 \mathrm{~s}$ from $10000 \mathrm{~V}$ to $5 \mathrm{~V}$ plus a wait-time of $34 \mathrm{~s}$, thus producing one average particle number size distribution every $7 \mathrm{~min}$. The detectable aerosol mobility diameters range from 11.1 to $1083.3 \mathrm{~nm}$ (44 size bins) with a sheath and sample flow of $3 \mathrm{lpm}$ and $0.3 \mathrm{lpm}$, respectively. The sheath airflow $(3 \mathrm{lpm})$ was dried with a silica gel canister to a RH of $\sim 10 \%$ and then filtered through a HEPA before entering the differential mobility analyzer (DMA). The aerosol size distributions were therefore measured under dry conditions, and hygroscopic growth was not considered. For simplicity, we hereafter refer to the measureable size range as $10-1000 \mathrm{~nm}$ (as opposed to 11.1 to $1083.3 \mathrm{~nm}$ ).

The size distributions inversion was carried out using the manufacturer-provided software (GRIMM 5.477 Version 1.35 Build 1), developed and described in detail by Reischl (1991). In the software, the DMA and CPC correction efficiencies were taken into account in the calculations, whereas the charging correction is only available for single channel measurements and therefore not applied to the size distribution (i.e., multiple channels) measurements. To minimize multiple charging from large particles, an impactor with a nozzle diameter of $0.6 \mathrm{~mm}$ and $50 \%$ size-cut of $1082 \mathrm{~nm}$ was attached to the inlet of the neutralizer and DMA. The SMPS has been routinely sent back to the manufacturer for calibration each year. In addition, the sizing accuracy was determined before the study by classifying $\mathrm{NaCl}$ of known mobility sizes $(50,76,113,168$, and $241 \mathrm{~nm})$ from a monodisperse aerosol generator (TSI; Model 3475), simultaneously with another SMPS (TSI; Model 3936). The differences between the expected and the measured particle sizes were less than $3 \mathrm{~nm}$. The aerosol size distribution data were then subjected to quality control and assurance procedures proposed by Yu et al. (2004) that screen for abnormal size distributions. Only less than $0.1 \%$ of aerosol data were identified as outliers and not included in the analysis. Following, the sizesegregated particle number concentrations were derived by integrating the number concentrations of particles between $10-25,25-100,10-100$ and $100-1000 \mathrm{~nm}$. These concentrations hereafter are denoted as $N_{10-25}, N_{25-100}, N_{10-100}$ and $N_{100-1000}$, respectively. Hourly aerosol data were then computed to synchronize with the gas pollutants and meteorological data.

On-site air quality and meteorological data were obtained from the monitoring sites and validated by the Taiwan Environmental Protection Administration (TW EPA, 2009). At the sites, $\mathrm{PM}_{10}$ and $\mathrm{PM}_{2.5}$ were continuously monitored by means of $\beta$-ray attenuation (Met One Instruments, Oregon, USA, Model BAM-1020), $\mathrm{SO}_{2}$ by UV fluorescence (Ecotech, Victoria, Australia, Model 9850 ), $\mathrm{NO}_{\mathrm{x}}$ by chemiluminescence (Ecotech, Victoria, Australia, Model 9841), CO by nondispersive IR (Horiba, Kyoto, Japan), and $\mathrm{O}_{3}$ by UV absorption (Ecotech, Victoria, Australia, Model 9810). Meteorological parameters used in the present study include temperature, relative humidity $(\mathrm{RH})$, wind speed, wind direction and UV index (UVI). The UVI ( $\left.1 \mathrm{UVI}=25 \mathrm{~mW} \mathrm{~m}^{-2}\right)$ was used in the calculation of UVB intensity. The evolution of the mixing height was estimated using the web-based Real-time Environmental Applications and Display sYstem (READY) from the Air Resources Laboratory of NOAA (http://ready. arl.noaa.gov/READYamet.php). The archive data were from the Global Data Assimilation System of National Centers for Environmental Prediction, which has a temporal and spatial resolution of $3 \mathrm{~h}$ and $1^{\circ}$ of latitude and longitude, respectively.

\subsection{NPF, growth and shrinkage event identification}

A comprehensive review of the present instrumentation, best practices and other tools for studying atmospheric nucleation and NPF has recently been presented by Kulmala et al. (2012). In this study, the identification of NPF events, as well as growth and shrinkage, was made visually on a daily basis according to a set of distinct features in the temporal evolution of the aerosol number size distributions (e.g., Dal Maso et al., 2005; Stanier et al., 2004). An NPF event is characterized by a substantial increase of $N_{10-25}$ followed by intense particle growth over a course over $1.5 \mathrm{~h}$, in which the nucleation and growth rates can be determined with a good confidence level. The start and end time of NPF ( $t_{\text {start }}$ and $\left.t_{\text {end }}\right)$ is defined as the time when the $N_{10-25}$ begin to rise sharply and when the particle growth stops, respectively. The $t_{\text {start }}$ is an important parameter as it indirectly relates to the specific atmospheric conditions (such as mixing 
height, temperature, and $\mathrm{RH}$ ) and the traffic emission source strength, both of which exhibit strong temporal dependence. Particle shrinkage refers to the continuous decrease of particle sizes over $\sim 2 \mathrm{~h}$ following their prior formation and growth.

\subsection{Determination of particle formation, nucleation and growth rate}

The empirical formation and nucleation rates $(J)$ during the NPF events were determined by a simplified approximation and an inverse modeling, respectively. The two methods are based on the general dynamic equation (GDE) in describing the evolution of aerosol size distribution (Seinfeld and Pandis, 2006). According to Dal Maso et al. (2005), the simplified GDE method determines the formation rate of $10 \mathrm{~nm}$ particles as follows:

$J_{\mathrm{d}}=\frac{\mathrm{d} N_{10-25}}{\mathrm{~d} t}+F_{\text {coag }}+F_{\text {growth }}$

where $N_{10-25}$ is the number concentration of nucleated particles, $F_{\text {coag }}$ is the loss of particles due to coagulation, and $F_{\text {growth }}$ is the flux of particles out of the nucleated particle size range. The smallest measurable particle size was $\sim 10 \mathrm{~nm}$ in this study, while the upper size range of the nucleated particle was set at $25 \mathrm{~nm}$. Hence, the formation rate of $10 \mathrm{~nm}$ particles is hereafter denoted as $J_{10}$. Assuming the homogeneous air mass with a constant source rate, $\mathrm{d} N_{10-25} / \mathrm{d} t$ was determined by a linear fit between $N_{10-25}$ and $t$. In the same fashion, the modal growth rate $\left(\mathrm{GR}_{\mathrm{MOD}}\right)$ was determined between the particle mode diameter $\left(D_{\text {mode }}\right)$ and $t$. $F_{\text {coag }}$ was computed from (Dal Maso et al., 2005):

$F_{\text {coag }}=N_{10-25} \sum_{j} K_{i j} N_{j}$

where the summation of $K_{i j} N_{j}$ is also known as the coagulation sink. $N_{j}$ is the number concentration of size bin $j . K_{i j}$ is the coagulation coefficient between size bin $i$ (i.e., the reference) and $j$, and takes the below form (Seinfeld and Pandis, 2006):

$K_{i j}=2 \pi\left(d_{i}+d_{j}\right)\left(D_{i}+D_{j}\right) \beta_{\mathrm{F}}$

where $d$ is the midpoint diameter of a size bin, $D$ and $\beta_{\mathrm{F}}$ are the size-dependent diffusion coefficient and Fuchs correction factor, respectively. It is noted that particle loss due to self-coagulation was neglected because of its minor contribution to NPF and growth, compared with inter-coagulation and condensation, especially in polluted environments (Anttila et al., 2010). $F_{\text {growth }}$ was also neglected for simplicity, but in the present study the particles appeared to grow relatively fast (e.g., to above $25 \mathrm{~nm}$ within the first several hours). As a result, the above method underestimated the actual $J_{10}$ because the particle transport losses and $F_{\text {growth }}$ were both neglected.

The inversion model known as Particle Growth and Nucleation (PARGAN) has been used here to estimate the $J$ and to supplement the $J_{10}$, and its development and application have been described elsewhere (Verheggen and Mozurkewich, 2006; Erupe et al., 2010; Metzger et al., 2010). The online version of PARGAN is available at http:// www.personal.kent.edu/ slee19/softwares.htm. In brief, the model implements a non-linear regression analysis of the GDE to fit the temporal evolution of the measured particle number size distributions. As such, the growth rate (GRPARGAN) as a function of time can be determined and then used to estimate the time when the nucleation begins. Such highly time-resolved approach is therefore sensitive to any noise or variability in the measured size distributions. In this work, we assume the critical cluster has a diameter of $1 \mathrm{~nm}$ (Sipila et al., 2010). The $J_{1}$ is then derived by integrating particle losses from the time of nucleation to the time of measurement. This approach thus differs from others, because the GRPARGAN is determined using a range of size intervals instead of total or modal particle number concentration and the $J_{1}$ is calculated solely on the basis of the measured size distributions, hence independent of any nucleation theories or parameterizations. The uncertainty therefore depends largely on the amount of extrapolation necessary to derive the correction factors for size-dependent particle number reductions (e.g., coagulation and dilution). These correction factors in turn depend on the assumed critical cluster size and the measured size distributions. Thus, erroneous assumption about the critical size and "noisy" measured size distributions will lead to increased uncertainty. In an atmospheric NPF study (Verheggen and Mozurkewich, 2002) and a smog chamber study (Verheggen and Mozurkewich, 2006), the authors estimated that the overall uncertainty of the PARGAN derived $J$ to be a factor of 2 to 3 , which is within an acceptable order-of-magnitude limit reported for other NPF analysis tools by Korhonen et al. (2011). It is nevertheless recommended that the interpretation and comparisons of modeling results should be proceeded with cautions. Unless equipped with instruments capable of detecting $\sim 1 \mathrm{~nm}$ particles, the highly time-resolved PARGAN approach still provides useful information and reference about the mechanism and intensity of atmospheric nucleation.

\subsection{Calculation of condensation sink, condensable vapour and $\mathrm{H}_{2} \mathrm{SO}_{4}$ proxy concentration}

Condensation sink (CS) is a measure of loss rate of $\mathrm{H}_{2} \mathrm{SO}_{4}$ vapor on pre-existing particles and is proportional to the surface area density of aerosol particles. Elevated pre-existing particles can suppress aerosol nucleation by scavenging freshly nucleated particles and condensable vapors. Assuming $\mathrm{H}_{2} \mathrm{SO}_{4}$ as the condensable species, the CS in the transition regime was calculated as follows (Kulmala et al., 2001):

$\mathrm{CS}=2 \pi D_{\mathrm{v}} \sum_{j} d_{j} \beta_{m, j} N_{j}$ 
where $D_{\mathrm{v}}$ is the diffusion coefficient of $\mathrm{H}_{2} \mathrm{SO}_{4}$ $\left(0.104 \mathrm{~cm}^{2} \mathrm{~s}^{-1}\right)$ estimated by the FSG-LaBas method (Lyman et al., 1990), and $\beta_{\mathrm{m}}$ is the size dependent transitional correction factor (Fuchs and Sutugin, 1971).

Based on the observed growth rates and assuming the condensable vapor was solely $\mathrm{H}_{2} \mathrm{SO}_{4}$, the condensable vapor concentration $(C)$ can be estimated according to Kulmala et al. (2005) as follows:

$$
\begin{aligned}
C & =\frac{\rho}{\Delta t D m_{\mathrm{v}}}\left(\frac{d_{\mathrm{p}}^{2}-d_{\mathrm{p}, 0}^{2}}{8}+\left(\frac{2}{3 \alpha}-0.312\right) \lambda\left(d_{\mathrm{p}}-d_{\mathrm{p}, 0}\right)\right. \\
& \left.+0.623 \lambda^{2} \ln \frac{2 \lambda+d_{\mathrm{p}}}{2 \lambda+d_{\mathrm{p}, 0}}\right)
\end{aligned}
$$

where $\rho$ is the particle density $\left(1.84 \mathrm{~g} \mathrm{~cm}^{-3}\right), D$ is the diffusion coefficient $\left(0.104 \mathrm{~cm}^{2} \mathrm{~s}^{-1}\right), m_{\mathrm{v}}$ is the molecular mass of the condensable vapor $\left(1.63 \times 10^{-22} \mathrm{~g} \mathrm{molec}^{-1}\right), \alpha$ is the mass accommodation coefficient (1), and $\lambda$ is the mean free path $\left(6.7 \times 10^{-6} \mathrm{~cm}\right)$ at $1 \mathrm{~atm}$ and $298 \mathrm{~K}$.

Ambient gas phase $\mathrm{H}_{2} \mathrm{SO}_{4}$ is known to be involved in the NPF and their subsequent growth. Its production and concentration depend on the precursor $\mathrm{SO}_{2}$ and $\mathrm{OH}$ concentrations, between which the latter is dependent on the photolysis rate of $\mathrm{O}_{3}$ by solar radiation in the 280-320 nm UVB range. Its major sink is condensation to pre-existing aerosols. In the cases where direct measurements are unavailable, a few methods have been proposed to estimate $\mathrm{H}_{2} \mathrm{SO}_{4}$ proxy concentrations. Here, we have adopted the proxy estimation method of $\mathrm{H}_{2} \mathrm{SO}_{4}$ concentration $(P)$ by Petäjä et al. (2009) as follows:

$P=k P^{\prime}=k \frac{\left[\mathrm{SO}_{2}\right] \mathrm{UVB}}{\mathrm{CS}}$

where $k$ is the scaling factor and CS is the condensation sink. The $\mathrm{SO}_{2}$ concentration has unit of $\mathrm{cm}^{-3}$. In this study, the UVB was determined from the measured daily maximum UVI, where 1 UVI equals to $25 \mathrm{~mW} \mathrm{~m}^{-2}$ (or $90 \mathrm{~J} \mathrm{~m}^{-2}$ ).

\section{Results and discussion}

\subsection{Characteristic time of NPF events in Taiwan}

Among the 137 sampling days at the four observation sites, we identified 14 intense NPF events. The NPF and growth date, time, duration and daily meteorological conditions are summarized in Table 1. As shown, 11 of them took place in the warm season (August-September) and three in the cold season (December-January). In addition, nine events occurred at the urban site, four at the downwind site, one at the coastal site, and none at the mountain site. The mountain site had the highest average $\mathrm{PM}_{2.5}$ of 47.7 and $36.9 \mu \mathrm{g} \mathrm{m}^{-3}$, whereas the $\mathrm{PM}_{10}$ were 66.7 and $49.3 \mu \mathrm{g} \mathrm{m}^{-3}$ in the cold and warm study season, respectively (Young et al., 2012). The high PM levels thus may have suppressed the NPF. All the events, except one (17 December 2008), started before $\sim$ 10:30 LT and ended before $\sim$ 15:00 LT. These $t_{\text {start }}$ and $t_{\text {end }}$ are similar to those observed in Beijing, China (Wu et al., 2007), Pittsburg, PA, USA (Stanier et al., 2004) and Hyytiälä, Finland (Boy and Kulmala, 2002). Nevertheless, some NPF events were limited to morning hours, whereas others occurred during midday hours. The duration $(\Delta t)$ from the start of NPF to the end of particle growth lasted for 1.5 to $5 \mathrm{~h}$. It is notable that eight NPF events took place over consecutive days (10-17 August 2010) at the urban site in the warm season (Fig. A1). Furthermore, in five of the 14 NPF events, the growth was immediately followed by intense particle shrinkage. Four shrinkage events were observed in the warm season with two at the urban site and the other two at the downwind site, and only one in the cold season at the coastal site. On event days, the ambient temperature and $\mathrm{RH}$ were below $18^{\circ} \mathrm{C}$ and $67 \%$ in the cold season, whereas mostly above $27^{\circ} \mathrm{C}$ and $69 \%$ in the warm season. The wind speeds were considerable stagnant (mostly $<1.3 \mathrm{~m} \mathrm{~s}^{-1}$ ) during all the event days except the one at the coastal site. The prevailing winds were from the northeast in the cold season whereas from the south or east in the warm season.

\subsection{Air pollutants, condensable vapor and $\mathrm{H}_{2} \mathrm{SO}_{4}$ proxy concentrations}

The daily $\mathrm{PM}_{2.5}, \mathrm{CS}, \mathrm{SO}_{2}$, condensable vapor and $\mathrm{H}_{2} \mathrm{SO}_{4}$ proxy concentrations during event days are given in Table 2. As shown, the $\mathrm{PM}_{2.5}$ were typically below $20 \mu \mathrm{g} \mathrm{m}^{-3}$, substantially lower than the annual average value of the hourly $\mathrm{PM}_{2.5}\left(35.8 \mu \mathrm{g} \mathrm{m}^{-3}\right)$. Only three event days had $\mathrm{PM}_{2.5}$ above $26.4 \mu \mathrm{g} \mathrm{m}^{-3}$ and up to $46.6 \mu \mathrm{g} \mathrm{m}^{-3}$. The daily $\mathrm{CS}$ and $\mathrm{SO}_{2}$ were in the range of $1.6-3.9 \times 10^{-2} \mathrm{~s}^{-1}$ and $2.0-4.6 \mathrm{ppb}$, respectively. The above $\mathrm{PM}_{2.5}$ and CS on event days were similar to, whereas the $\mathrm{SO}_{2}$ were lower than those observed in Pittsburg, PA (Stanier et al., 2004) and Beijing, China (Wu et al., 2007). Figure 2 compares the daily $\mathrm{CS}$ and $\mathrm{SO}_{2}$ between non-event and event days. As shown, both the CS and $\mathrm{SO}_{2}$ on event days were typically below the median values on non-event days; for reference, the median CS for the entire study period is $2.6 \times 10^{-2} \mathrm{~s}^{-1}$. This indicates that the NPF events were favored on days with low concentrations of both pre-existing particles and $\mathrm{SO}_{2}$. The preference for low $\mathrm{SO}_{2}$ is somewhat counterintuitive as it is the precursor of the major nucleating vapor $\mathrm{H}_{2} \mathrm{SO}_{4}$. Nevertheless, the lower or comparable $\mathrm{SO}_{2}$ on event days than on non-event days suggests that $\mathrm{SO}_{2}$ was not a limiting factor for NPF. For example, Salma et al. (2011) found that the $\mathrm{SO}_{2}$ (yearly median $2.6 \mathrm{ppb}$ ) is always in excess for NPF in Budapest, Hungary. In this study, there are several possible reasons to the rather counterintuitive preference for low $\mathrm{SO}_{2}$ : first, the minimum $\mathrm{SO}_{2}$ of $\sim 2.0 \mathrm{ppb}$ at the observation sites is already sufficient for NPF. Second, the rate-limiting step in the production of $\mathrm{H}_{2} \mathrm{SO}_{4}$ involves the oxidation of $\mathrm{SO}_{2}$ by $\mathrm{OH}$. Therefore, elevated $\mathrm{SO}_{2}$ alone does not necessarily warrant 
Table 1. The NPF and growth event date, time, duration, and daily averages of ambient temperature $(T)$, relative humidity (RH), wind speed, and prevailing wind direction at the observation sites.

\begin{tabular}{|c|c|c|c|c|c|c|c|c|c|c|}
\hline \multirow[b]{2}{*}{ Date } & \multirow[b]{2}{*}{ Site $^{1}$} & \multirow{2}{*}{$\begin{array}{l}\text { Day of } \\
\text { the Week }\end{array}$} & \multirow[b]{2}{*}{ Shrink $^{2}$} & \multicolumn{2}{|c|}{ Start/End time } & \multirow[b]{2}{*}{$\Delta \mathrm{t}^{3}$} & \multirow{2}{*}{$\begin{array}{l}T \\
\left({ }^{\circ} \mathrm{C}\right)\end{array}$} & \multirow{2}{*}{$\begin{array}{l}\mathrm{RH} \\
(\%)\end{array}$} & \multirow{2}{*}{$\begin{array}{l}\text { Wind Speed } \\
\left(\mathrm{m} \mathrm{s}^{-1}\right)\end{array}$} & \multirow{2}{*}{$\begin{array}{l}\text { Prevailing } \\
\text { Wind Direction }\end{array}$} \\
\hline & & & & $t_{\text {start }}$ & $t_{\text {end }}$ & & & & & \\
\hline 3 Dec 2008 & $\mathrm{D}$ & Wed. & No & $10: 18$ & $15: 03$ & $04: 44$ & 18 & 66 & 0.6 & E \\
\hline 17 Dec 2008 & $\mathrm{U}$ & Wed. & No & $12: 02$ & $13: 57$ & 01:55 & 18 & 59 & 0.5 & $\mathrm{~N}, \mathrm{NE}$ \\
\hline 3 Jan 2009 & $\mathrm{C}$ & Sat. & Yes & $10: 31$ & $13: 26$ & $02: 55$ & 16 & 64 & 3.4 & $\mathrm{~N}$ \\
\hline 10 Aug 2010 & $\mathrm{U}$ & Tue. & No & $08: 17$ & $13: 11$ & $04: 54$ & 32 & 69 & 1.9 & $\mathrm{~S}, \mathrm{SW}$ \\
\hline 11 Aug 2010 & $\mathrm{U}$ & Wed. & No & $07: 37$ & $11: 56$ & $04: 19$ & 30 & 77 & 1.3 & S \\
\hline 12 Aug 2010 & $\mathrm{U}$ & Thu. & Yes & 08:07 & $12: 26$ & $04: 19$ & 30 & 74 & 1.2 & $\mathrm{~S}, \mathrm{SE}$ \\
\hline 13 Aug 2010 & $\mathrm{U}$ & Fri. & No & $07: 13$ & $12: 14$ & 05:00 & 30 & 71 & 1.2 & $\mathrm{~S}, \mathrm{~W}$ \\
\hline 14 Aug 2010 & $\mathrm{U}$ & Sat. & No & $08: 59$ & $13: 32$ & $04: 33$ & 31 & 72 & 1.2 & $\mathrm{~S}, \mathrm{~W}$ \\
\hline 15 Aug 2010 & $\mathrm{U}$ & Sun. & No & $08: 54$ & $10: 32$ & $01: 38$ & 30 & 71 & 1.0 & $\mathrm{~S}, \mathrm{SE}$ \\
\hline 16 Aug 2010 & $\mathrm{U}$ & Mon. & Yes & $08: 28$ & 11:09 & $02: 41$ & 30 & 70 & 1.2 & $\mathrm{~S}$ \\
\hline 17 Aug 2010 & $\mathrm{U}$ & Tue. & No & 09:05 & $12: 35$ & $03: 30$ & 30 & 72 & 0.7 & SE \\
\hline 5 Sep 2010 & $\mathrm{D}$ & Sun. & Yes & $09: 40$ & $11: 53$ & $02: 13$ & 27 & 83 & 1.1 & NW, SW \\
\hline 7 Sep 2010 & $\mathrm{D}$ & Tue. & Yes & $10: 07$ & $12: 41$ & $02: 34$ & 28 & 82 & 1.1 & SW, NW \\
\hline 12 Sep 2010 & $\mathrm{D}$ & Sun. & No & 09:07 & $13: 26$ & 04:19 & 26 & 84 & 0.9 & $\mathrm{~W}$ \\
\hline
\end{tabular}

\footnotetext{
1 The four observation sites: $\mathrm{U}$ indicates urban, $\mathrm{C}$ coastal and D downwind site. There were no NPF events observed at the mountain site.

2 "Yes" for days with particle shrinkage following their prior formation and growth.

3 The duration between the start of NPF to the end of particle growth.
}

increased production of $\mathrm{H}_{2} \mathrm{SO}_{4}$. Third, elevated $\mathrm{SO}_{2}$ are often accompanied with elevated CS, particularly in urban air or industrial plumes. In this study, for example, the daily $\mathrm{SO}_{2}$ were positively correlated with $\mathrm{CS}, \mathrm{PM}_{2.5}, \mathrm{NO}_{\mathrm{x}}$ and $\mathrm{CO}$ with the correlation coefficients of $0.38,0.30,0.26$ and 0.23 , respectively. The elevated CS as well as co-pollutants may have scavenged a significant fraction of $\mathrm{H}_{2} \mathrm{SO}_{4}$, hence suppressing the NPF and growth. Figure A2 presents the diurnal variations of the average mixing height, $\mathrm{NO}_{\mathrm{x}}, \mathrm{CO}, \mathrm{CS}, \mathrm{SO}_{2}$ and $N_{10-100}$ concentrations on non-event and event days. It clearly shows the aforementioned positive correlations between those air pollutants, despite that the differences of hourly pollutant levels were insignificance between the nonevent and event days.

The derived condensable vapor concentrations $(C)$ required to explain the observed particle growth in this study ranged from $1.69 \times 10^{8} \mathrm{~cm}^{-3}$ to $6.59 \times 10^{8} \mathrm{~cm}^{-3}$, with an average of $3.46 \pm 1.49 \times 10^{8} \mathrm{~cm}^{-3}$. These levels are comparable to that estimated for polluted New Delhi, India and thus the source rates of $>10^{7}-10^{8} \mathrm{~cm}^{-3} \mathrm{~s}^{-1}$ (i.e., the product of $\mathrm{CS}$ and $C$ ) are a few orders of magnitude stronger than those in clean environments reported by Kulmala et al. (2005). On the other hand, using the $\mathrm{k}$-value of $9.9 \times 10^{-7} \mathrm{~m}^{2} \mathrm{~W}^{-1} \mathrm{~s}^{-1}$ reported by Petäjä et al. (2009), the $\mathrm{H}_{2} \mathrm{SO}_{4}$ proxy concentration $(P)$ ranged from $1.72 \times 10^{7} \mathrm{~cm}^{-3}$ to $7.79 \times 10^{7} \mathrm{~cm}^{-3}$, with an average of $4.18 \pm 1.76 \times 10^{7} \mathrm{~cm}^{-3}$. It is important to note that these derived P-values represent the upper limits because we have used the daily maximum UVI in the estimations. Most field observations have shown that the atmospheric $\mathrm{H}_{2} \mathrm{SO}_{4}$ concentrations during NPF were typically on

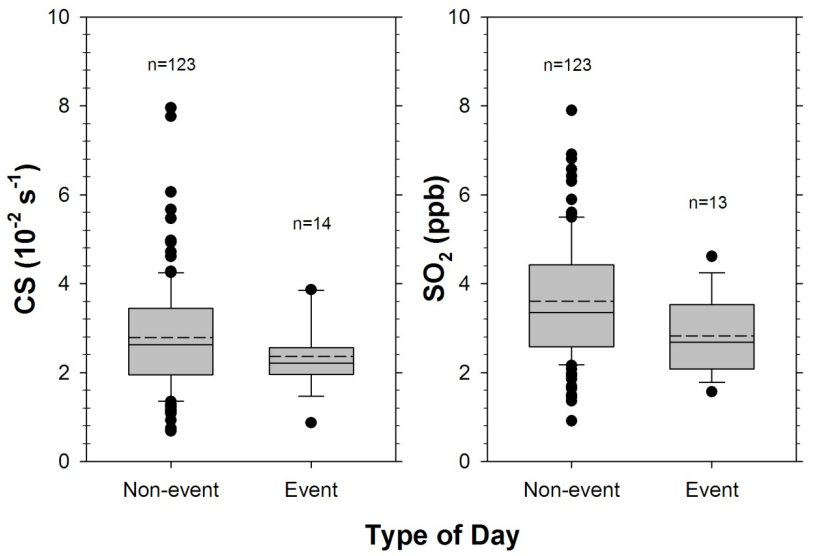

Fig. 2. Boxplots of the daily condensation sink (CS) and $\mathrm{SO}_{2}$ for non-event and event days. The solid and dash line inside the box is the median and mean, respectively; the $n$ is the number of days and the whiskers mark the 10th and 90th percentile.

the order of $10^{6}-10^{7} \mathrm{~cm}^{-3}$ (e.g., Riipinen et al., 2007; Kuang et al., 2008; Yue et al., 2010).

\subsection{Particle concentrations, formation, growth and shrinkage rates}

The size-segregated particle number concentration, formation/nucleation and growth/shrinkage rates during the NPF events are summarized in Table 3. To illustrate the NPF intensity, the particle number concentrations during NPF events are compared to average levels at the same sites and the same 
Table 2. The daily averages of $\mathrm{PM}_{2.5}$, condensation sink (CS), $\mathrm{SO}_{2}$, condensable vapor (C) and $\mathrm{H}_{2} \mathrm{SO}_{4}$ proxy $(\mathrm{P})$ concentrations during the NPF event days.

\begin{tabular}{llllllll}
\hline Date & Site $^{1}$ & Shrink $^{2}$ & $\begin{array}{l}\mathrm{PM}_{2.5} \\
\left(\mu \mathrm{g} \mathrm{m}^{-3}\right)\end{array}$ & $\begin{array}{l}\mathrm{CS} \\
\left(10^{-2} \mathrm{~s}^{-1}\right)\end{array}$ & $\begin{array}{l}\mathrm{SO}_{2} \\
(\mathrm{ppb})\end{array}$ & $\begin{array}{l}\mathrm{C} \\
\left(10^{8} \mathrm{~cm}^{-3}\right)\end{array}$ & $\begin{array}{l}\mathrm{P}^{3} \\
\left(10^{7} \mathrm{~cm}^{-3}\right)\end{array}$ \\
\hline 3 Dec 2008 & $\mathrm{D}$ & No & 46.6 & 3.9 & 3.4 & 2.08 & 1.72 \\
17 Dec 2008 & $\mathrm{U}$ & No & 40.4 & 3.2 & 3.3 & 6.59 & - \\
3 Jan 2009 & $\mathrm{C}$ & Yes & 19.4 & 2.2 & 3.7 & 1.93 & 2.46 \\
10 Aug 2010 & $\mathrm{U}$ & No & 17.9 & 2.1 & 3.5 & 4.73 & 5.98 \\
11 Aug 2010 & $\mathrm{U}$ & No & 15.8 & 2.4 & 2.8 & 2.72 & 3.04 \\
12 Aug 2010 & $\mathrm{U}$ & Yes & 18.9 & 2.0 & 2.6 & 3.09 & 4.92 \\
13 Aug 2010 & $\mathrm{U}$ & No & 17.0 & 1.9 & 2.1 & 1.69 & 3.20 \\
14 Aug 2010 & $\mathrm{U}$ & No & 17.0 & 2.2 & 2.3 & 4.59 & 3.55 \\
15 Aug 2010 & $\mathrm{U}$ & No & 16.5 & 2.0 & 2.0 & 2.32 & 3.46 \\
16 Aug 2010 & $\mathrm{U}$ & Yes & 17.0 & 2.2 & - & 5.00 & - \\
17 Aug 2010 & $\mathrm{U}$ & No & 19.0 & 2.6 & 4.6 & 4.05 & 6.36 \\
5 Sep 2010 & $\mathrm{D}$ & Yes & 15.5 & 1.7 & 2.1 & 4.51 & 3.94 \\
7 Sep 2010 & $\mathrm{D}$ & Yes & 26.4 & 2.0 & 2.4 & 1.70 & 3.73 \\
12 Sep 2010 & $\mathrm{D}$ & No & 10.1 & 1.6 & 2.9 & 3.38 & 7.79 \\
\hline
\end{tabular}

${ }^{1}$ The four observation sites: $\mathrm{U}$ indicates urban, $\mathrm{C}$ coastal and D downwind site. There were no NPF events observed at the mountain site.

2 "Yes" for days with particle shrinkage following their prior formation and growth.

3 The $\mathrm{H}_{2} \mathrm{SO}_{4}$ proxy concentration assuming the scaling factor $k$ of $9.9 \times 10^{-7} \mathrm{~m}^{2} \mathrm{~W}^{-1} \mathrm{~s}^{-1}$ reported by Petäjä et al. (2009).

periods given by Young et al. (2012). The average $N_{10-25}$ during the NPF and growth events were in the range of 1.2$4.0 \times 10^{4} \mathrm{~cm}^{-3}$, which were $\sim 1.7$ to 5.7 times higher than average levels of $0.7 \times 10^{4} \mathrm{~cm}^{-3}$. The average $N_{25-100}$ were in the range of $1.3-3.3 \times 10^{4} \mathrm{~cm}^{-3}$, which were $\sim 1.2$ to 3.0 times higher than average levels of $1.1 \times 10^{4} \mathrm{~cm}^{-3}$. It is clear that the NPF events resulted in substantial increases of the $N_{10-100}$ (i.e., UFPs). As shown in the hourly data (Fig. A2), the peak $N_{10-100}$ at 10:00 LT on event days were preceded by a decrease of CS, coincided with a slight increase of $\mathrm{SO}_{2}$ and strong atmospheric dilution, and lagged $2 \mathrm{~h}$ behind the traffic $\mathrm{CO}$ and $\mathrm{NO}_{\mathrm{x}}$ peaks. These results suggest that the elevated $N_{10-100}$ at 10:00 LT were not emitted directly from motor vehicles but formed shortly afterwards in the atmosphere. On non-event days, the diurnal variations of $N_{10-100}$ were nearly identical to those of $\mathrm{NO}_{\mathrm{x}}$ and $\mathrm{CO}$ (Fig. A2). This indicates that the particle number variability on nonevent days was largely driven by traffic emissions. Similar traffic-related $N_{10-100}$ peaks (i.e., ones that occurred at $\sim 08: 00 \mathrm{LT}$ ) were also observed at a downwind site in urban Budapest, Hungary (Salma et al., 2011). Although less common, the average $N_{10-100}$ of $7.5 \times 10^{4} \mathrm{~cm}^{-3}$ during NPF was $\sim 3.6$ times higher than that of $2.1 \times 10^{4} \mathrm{~cm}^{-3}$ emitted from the morning traffic. The approximation-derived formation rates of $10 \mathrm{~nm}$ particles $\left(J_{10}\right)$ during NPF events at the urban site were $7.0-30 \mathrm{~cm}^{-3} \mathrm{~s}^{-1}$, whereas at the coastal and downwind sites they were $4.4-15 \mathrm{~cm}^{-3} \mathrm{~s}^{-1}$. The coagulation loss $\left(F_{\text {coag }}\right.$ in Eq. 1) of the newly-formed $10-25 \mathrm{~nm}$ particles at the urban site accounted for $45-80 \%$ of the derived $J_{10}$, whereas at the coastal and downwind sites its contributions to $J_{10}$ were more variable, between $28-85 \%$. Overall, these losses on average accounted for $60 \pm 17 \%$ of the $J_{10}$. This shows that the apparent particle flux $(\mathrm{d} N / \mathrm{d} t)$ alone would have largely underestimated the $J_{10}$. The observed $J_{10}$ in this study are generally higher than that reported in the studies over a large number of measurements sites worldwide summarized by Kulmala et al. (2004). Recent studies showed that the $J_{3}$ in Hong Kong, Beijing, Shangdianzi and New Delhi were $1.8-5.1 \mathrm{~cm}^{-3} \mathrm{~s}^{-1}, 2.0-81 \mathrm{~cm}^{-3} \mathrm{~s}^{-1}, 0.7-73 \mathrm{~cm}^{-3} \mathrm{~s}^{-1}$ and 3.3-14 $\mathrm{cm}^{-3} \mathrm{~s}^{-1}$, respectively (Mönkkönen et al., 2005; Shen et al., 2011; Wu et al., 2007; Yao et al., 2010; Yue et al., 2010).

The PARGAN-derived nucleation rates $\left(J_{1}\right)$ during NPF events at the urban site were in the range of 132 $253 \mathrm{~cm}^{-3} \mathrm{~s}^{-1}$, whereas at the coastal and downwind sites they were in the range of $40-113 \mathrm{~cm}^{-3} \mathrm{~s}^{-1}$ (Table 2). The observed $J_{1}$ are inline with the modeled median nucleation rates of $311 \mathrm{~cm}^{-3} \mathrm{~s}^{-1}$ and $18 \mathrm{~cm}^{-3} \mathrm{~s}^{-1}$ in polluted boundary layer and the rural/continental background, respectively (Anttila et al., 2010; Kulmala et al., 2004), yet substantially lower than the nucleation rates of $3 \times 10^{5}-5 \times 10^{7} \mathrm{~cm}^{-3} \mathrm{~s}^{-1}$ in coastal areas (Pirjola et al., 2002). Using the same PARGAN method (Erupe et al., 2010; Kanawade et al., 2012), the median $J_{1}$ of $\sim 11 \mathrm{~cm}^{-3} \mathrm{~s}^{-1}$ in semi-rural Kent, $\mathrm{OH}$, USA, was substantially lower than the present study. This difference may be due to the substantially higher $\mathrm{SO}_{2}$ and other possible precursor nucleating vapors at the present observation sites. On the other hand, based on the growth rates and Fuchs surface area, Iida et al. (2008) estimated the $J_{1}$ in Mexico City and New Delhi were $1900-3000 \mathrm{~cm}^{-3} \mathrm{~s}^{-1}$ and $\sim 1300 \mathrm{~cm}^{-3} \mathrm{~s}^{-1}$, respectively. These values are substantially higher than the $J_{1}$ in this study, possibly because 
Table 3. The size-segregated particle number concentration, formation/nucleation and growth/shrinkage rates during the NPF events.

\begin{tabular}{|c|c|c|c|c|c|c|c|c|c|}
\hline \multirow[b]{2}{*}{ Date } & \multirow[b]{2}{*}{ Site $^{1}$} & \multirow[b]{2}{*}{ Shrink $^{2}$} & \multicolumn{2}{|c|}{$\begin{array}{l}\text { Number Conc. } \\
\qquad\left(10^{4} \mathrm{~cm}^{-3}\right)\end{array}$} & \multicolumn{2}{|c|}{$\begin{array}{l}\text { Formation/Nucleation } \\
\text { Rate }\left(\mathrm{cm}^{-3} \mathrm{~s}^{-1}\right)\end{array}$} & \multicolumn{3}{|c|}{$\begin{array}{l}\text { Growth/Shrinkage } \\
\text { Rate }\left(\mathrm{nm} \mathrm{h}^{-1}\right)\end{array}$} \\
\hline & & & $N_{10-25}$ & $N_{25-100}$ & $J_{10}$ & $J_{1}$ & $\mathrm{GR}_{\mathrm{MOD}}$ & $\mathrm{GR}_{\mathrm{MOD}}$ & GRPARGAN $_{\text {PAN }}$ \\
\hline 3 Dec 2008 & $\mathrm{D}$ & No & 2.0 & 1.3 & 15 & 113 & 7.4 & - & 6.7 \\
\hline 17 Dec 2008 & $\mathrm{U}$ & No & 1.7 & 1.4 & 7.0 & 182 & 24 & - & 6.6 \\
\hline 3 Jan 2009 & $\mathrm{C}$ & Yes & 2.2 & 1.7 & 7.2 & 99 & 7.8 & -5.1 & 15 \\
\hline 10 Aug 2010 & $\mathrm{U}$ & No & 3.3 & 2.5 & 16 & 195 & 15 & - & 8.5 \\
\hline 11 Aug 2010 & $\mathrm{U}$ & No & 3.9 & 2.5 & 30 & 253 & 9.3 & - & 7.2 \\
\hline 12 Aug 2010 & $\mathrm{U}$ & Yes & 3.0 & 2.5 & 16 & 216 & 11 & -5.6 & 7.4 \\
\hline 13 Aug 2010 & $\mathrm{U}$ & No & 3.5 & 2.9 & 18 & 209 & 6.7 & - & 9.1 \\
\hline 14 Aug 2010 & $\mathrm{U}$ & No & 2.9 & 3.0 & 25 & 203 & 13 & - & 6.5 \\
\hline 15 Aug 2010 & $\mathrm{U}$ & No & 4.0 & 3.2 & 27 & 172 & 7.6 & - & 8.4 \\
\hline 16 Aug 2010 & $\mathrm{U}$ & Yes & 3.9 & 3.3 & 23 & 188 & 17 & -6.9 & 9.5 \\
\hline 17 Aug 2010 & $\mathrm{U}$ & No & 2.9 & 2.9 & 22 & 132 & 13 & - & 8.2 \\
\hline 5 Sep 2010 & $\mathrm{D}$ & Yes & 1.4 & 2.4 & 4.4 & 40 & 15 & -7.1 & 12 \\
\hline 7 Sep 2010 & $\mathrm{D}$ & Yes & 1.6 & 1.5 & 8.4 & 82 & 7.4 & -7.6 & 7.8 \\
\hline 12 Sep 2010 & $\mathrm{D}$ & No & 1.2 & 2.2 & 11 & 65 & 11 & - & 9.6 \\
\hline
\end{tabular}

1 The four observation sites: U indicates urban, C coastal and D downwind site. There were no NPF events observed at the mountain site.

2 "Yes" for days with particle shrinkage following their prior formation and growth.

3 The average concentrations from the start of NPF to the end of particle growth.

the two megacities are substantially more polluted with respect to $\mathrm{SO}_{2}$ and PM than the present study area (Gurjar et al., 2008; Raga et al., 2001).

The PARGAN-derived growth rates $\left(\mathrm{GR}_{\mathrm{PARGAN}}\right)$ and approximation-derived $\mathrm{GR}_{\mathrm{MOD}}$ at the urban site were 6.5$9.5 \mathrm{~nm} \mathrm{~h}^{-1}$ and $6.7-24 \mathrm{~nm} \mathrm{~h}^{-1}$, respectively. At the coastal and downwind sites, they were $6.7-15 \mathrm{~nm} \mathrm{~h}^{-1}$ and $7.4-$ $15 \mathrm{~nm} \mathrm{~h}^{-1}$, respectively. The percentages of GRPARGAN over $\mathrm{GR}_{\mathrm{MOD}}$ ranged from $51 \%$ to $187 \%$, with an average of $88 \pm 41 \%$, similar to the percentage shown by Erupe et al. (2010). Thus, the differences between the GRPARGAN and $\mathrm{GR}_{\mathrm{MOD}}$ are within a factor of 2 , indicating reasonable consistency between the two different approaches to GR estimations.

The $\mathrm{GR}_{\mathrm{MOD}}$ during particle shrinkage in this study were between -5.1 and $-7.6 \mathrm{~nm} \mathrm{~h}^{-1}$, which were slightly smaller than that between -8.2 and $-10.7 \mathrm{~nm} \mathrm{~h}^{-1}$ observed in Hong Kong (Yao et al., 2010). The ratio of shrinkage-to-growth rates for each shrinkage event day was in the range of 0.40 0.66 , with an exception for the shrinkage event on the 7 September 2010 during which the ratio was 1.02. The evaporation loss of prior condensed vapor can be estimated by the particle volume change as a result of diameter shrinkage. The results show that on the 3 January 2009 and the 7 September 2010 the volume losses were above $90 \%$, suggesting nearly complete evaporation. On other remaining days, the volume losses ranged from $18 \%$ to $38 \%$. These results indicate that a notable fraction of the originally condensed chemical species evaporated from the particle phase to the gas phase under atmospheric conditions. Bzdek et al. (2012) recently showed that sulfate contributed to $41-46 \%$ new par- ticle growth, whereas $\mathrm{NO}_{3}^{-}, \mathrm{NH}_{4}^{+}$and organics contributed to the remaining 54-59\% growth. In particular, some of the latter chemical species are known to be semi-volatile and, as such, they have the potentials to evaporate off the new particles under favorable conditions.

A closer examination of the size distribution data reveals that the two shrinkage events ( 3 January 2009 and 5 September 2010) showed simultaneous decrease of particle size and $N_{10-25}$, similar to the Hong Kong shrinkage events (Yao et al., 2010). However, the other three shrinkage events (12 August, 16 August and 7 September 2010) showed decreasing particle size with increasing $N_{10-25}$. Furthermore, the grown particles in some cases can shrink back to the smallest measurable size of $\sim 10 \mathrm{~nm}$, whereas a few others are similar to the Hong Kong shrinkage events where the particle shrinking stopped at sizes above the smallest measurable size at $\sim 20 \mathrm{~nm}$ in our study (Fig. A3). As a result, the new particle growth and shrinkage creates a unique "arch-like" shape in the size distribution contour plot.

\subsection{Case studies of NPF and growth}

As described earlier in Sect. 3.1, all but one NPF events started before 10:30LT. Nevertheless, some events were more or less limited to morning hours, whereas others lasted into midday hours. Two typical examples of NPF and growth events are given below, one during morning hours and the other during midday hours. On the 17 August 2010 , the $N_{10-25}, \mathrm{CS}, \mathrm{CO}$ and $\mathrm{NO}_{\mathrm{x}}$ started to increase from 05:00 LT and then reached a maximum at $\sim$ 08:00 LT due to the increased traffic emissions during rush hours (Fig. 3). 

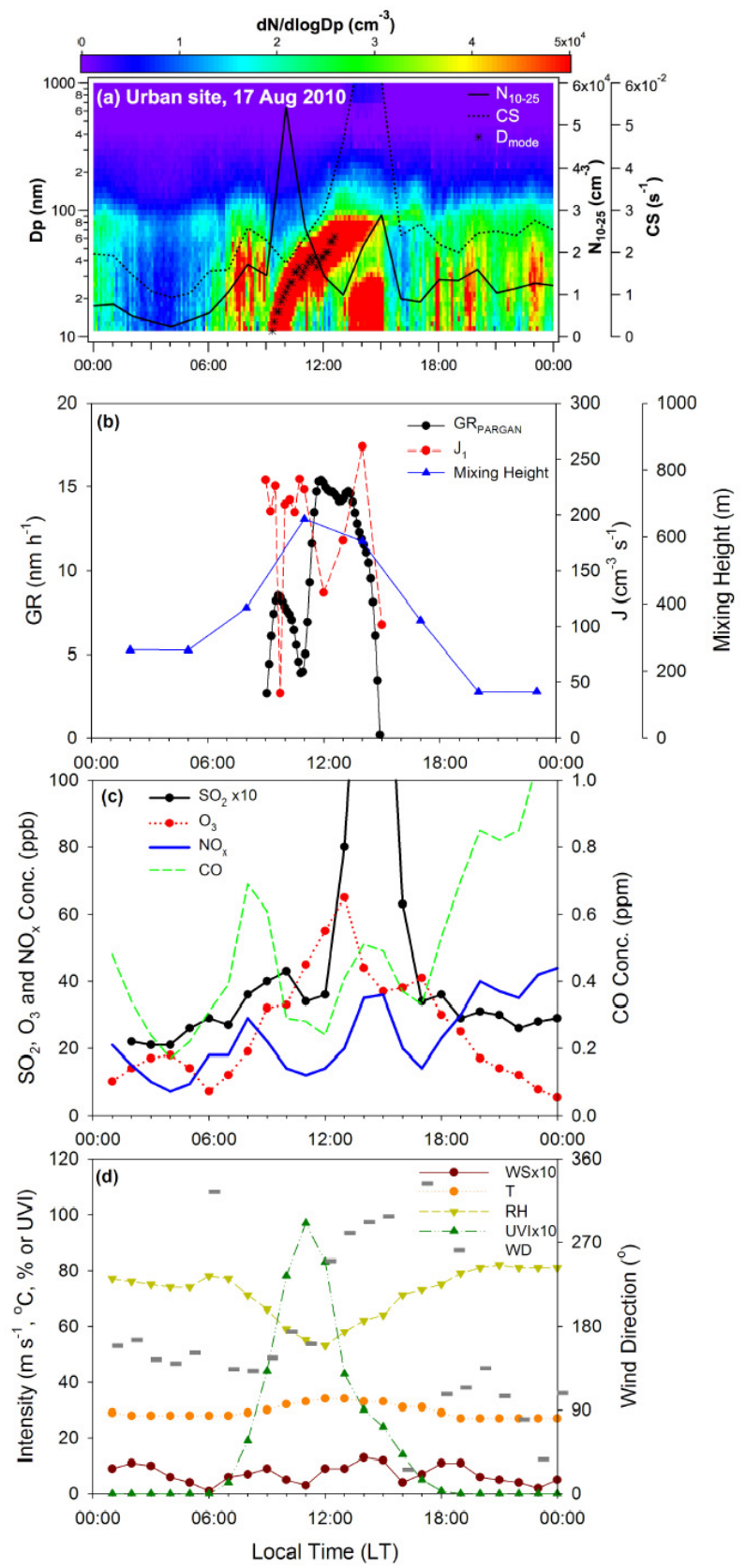

Fig. 3. The evolution of (a) the number size distributions, $N_{10-25}$, $\mathrm{CS}$ and particle mode diameter $\left(D_{\text {mode }}\right),(\mathbf{b})$ the GR $\mathrm{GARGAN}, J_{1}$ and mixing height, (c) the hourly $\mathrm{SO}_{2}, \mathrm{O}_{3}, \mathrm{NO}_{\mathrm{x}}$ and $\mathrm{CO}$, and (d) the meteorological conditions (WS, $T, \mathrm{RH}, \mathrm{WD}$ and UVI) during a morning NPF and growth event on the 17 August 2010.

The traffic-emitted $N_{10-25}$ at 08:00 LT had a maximum of $1.7 \times 10^{4} \mathrm{~cm}^{-3}$. Between 08:00 and 09:00 LT, the size distribution contour plot shows a significant decrease of particles larger than $50 \mathrm{~nm}$, indicating strong atmospheric dilution at that time. As a result, the primary pollutants $\mathrm{CO}, \mathrm{NO}_{\mathrm{x}}$ and $\mathrm{CS}$ decreased to a minimum at $\sim 10: 00$ LT. At about the same time, the $N_{10-25}$ sharply increased from $1.5 \times 10^{4} \mathrm{~cm}^{-3}$ to
$5.8 \times 10^{4} \mathrm{~cm}^{-3}$ at 10:00 LT. The $N_{10-25}$ peak coincided with a $\mathrm{SO}_{2}$ peak of $4.3 \mathrm{ppb}$, indicating possible involvement of $\mathrm{H}_{2} \mathrm{SO}_{4}$ (as opposed to direct traffic emissions) in NPF. It is important to note that the $\mathrm{SO}_{2}$ peak lagged $2 \mathrm{~h}$ after the $\mathrm{CO}$ and $\mathrm{NO}_{\mathrm{x}}$ peaks, thus suggesting the $\mathrm{SO}_{2}$ was not directly emitted from motor vehicles. The high level of $N_{10-25}$ was then followed by intense particle growth from 11 to $62 \mathrm{~nm}$ over a duration of $\sim 4 \mathrm{~h}$. The $J_{1}$ and GR PARGAN during the first $2 \mathrm{~h}$ of the event varied around $200 \mathrm{~cm}^{-3} \mathrm{~s}^{-1}$ and $5 \mathrm{~nm} \mathrm{~h}^{-1}$, respectively. The GR PARGAN then increased to $\sim 15 \mathrm{~nm} \mathrm{~h}^{-1}$ in the final few hours. Prior to 10:00 LT, the relatively light winds came from the southeast under a cloudless and sunny condition (9.7 UVI). The $\mathrm{O}_{3}$ had a maximum of $65 \mathrm{ppb}$ at 13:00 LT. Near the end of the NPF event, the winds became westerly and another $N_{10-25}$ peak was observed at 15:00 LT. Unlike the morning NPF event, this afternoon particle formation event was related to plume because of the concurrently elevated primary pollutants $\mathrm{SO}_{2}$ $(17 \mathrm{ppb}), \mathrm{NO}_{\mathrm{x}}(36 \mathrm{ppb})$ and $\mathrm{CO}(0.5 \mathrm{ppm})$, and a decrease of $\mathrm{O}_{3}(37 \mathrm{ppb})$. In addition, there was no particle growth following the particle formation, possibly because of the extremely high CS $\left(7.1 \times 10^{-2} \mathrm{~s}^{-1}\right)$ and decreased photochemical activities (low UVI and $\mathrm{O}_{3}$ ).

As opposed to the previous morning NPF, the following example occurred during midday hours that are typically characterized by low concentrations of primary pollutants $\mathrm{CO}$ and $\mathrm{NO}_{\mathrm{x}}$, but elevated $\mathrm{O}_{3}$ and mixing height (Fig. A2). On the 3 December 2008, the $N_{10-25}, \mathrm{CO}$ and $\mathrm{NO}_{\mathrm{x}}$ started to increase from 05:00 LT and then reached a maximum at $\sim$ 08:00 LT (Fig. 4). The traffic-emitted $N_{10-25}$ at 08:00 LT had a maximum of $1.4 \times 10^{4} \mathrm{~cm}^{-3}$, which is similar to that observed on other event days. After 08:00 LT, the CO and $\mathrm{NO}_{\mathrm{x}}$ then decreased substantially due to decreased source strength and increased mixing height. Strong atmospheric dilution caused the CS to drop to a minimum of $2.2 \times 10^{-2} \mathrm{~s}^{-1}$ at 13:00 LT. At about the same time, the $N_{10-25}$ increased sharply from $0.5 \times 10^{4} \mathrm{~cm}^{-3}$ to $3.5 \times 10^{4} \mathrm{~cm}^{-3}$ within an hour. The only pollutant that coincided with the $N_{10-25}$ peak was the $\mathrm{SO}_{2}(5 \mathrm{ppb})$. Similar to the previous example, the $\mathrm{SO}_{2}$ peak lagged $4 \mathrm{~h}$ after the $\mathrm{CO}$ and $\mathrm{NO}_{\mathrm{x}}$ peaks, suggesting the $\mathrm{SO}_{2}$ was not directly emitted from motor vehicles. The NPF event was then followed by intense particle growth from 11 to $39 \mathrm{~nm}$ during the following two hours. The $J_{1}$ reached as high as $\sim 300 \mathrm{~cm}^{-3} \mathrm{~s}^{-1}$ at 12:30 LT, whereas the GRPARGAN were in the range of $2-10 \mathrm{~nm} \mathrm{~h}^{-1}$. The southeasterly winds in the morning were stagnant $\left(<0.6 \mathrm{~m} \mathrm{~s}^{-1}\right)$. Afterwards, the wind direction changed to northerly and the wind speed increased significantly to above $1 \mathrm{~m} \mathrm{~s}^{-1}$. The UVI indicates it was a cloudless, sunny day. Despite the maximum UVI of 5.2 at 12:00 LT was relatively weak (compared to Fig. 3d), the $\mathrm{O}_{3}$ peak of $84 \mathrm{ppb}$ at 16:00 LT was significantly higher than that at the urban site in the warm season (e.g., Fig. 3c; 65 ppb $\mathrm{O}_{3}$ ). This suggests that photochemical activities could be quite strong at the downwind site in the cold season. The termination of the midday NPF event 


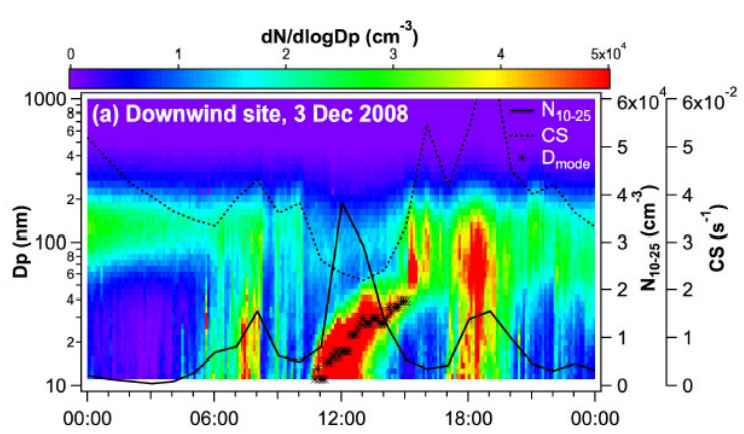

From above and other events in this study, we observed that the onset of morning or midday NPF events coincided with decreases of $\mathrm{CS}$ and increases of $\mathrm{SO}_{2}$ during periods (09:00-13:00 LT) with enhanced atmospheric mixing and dilution. The decrease of CS, as well as traffic-emitted $\mathrm{CO}$ and $\mathrm{NO}_{\mathrm{x}}$, due to dilution is rather expected; however, the increase of $\mathrm{SO}_{2}$ suggests it was not from local traffic emissions but likely from power plant or industrial plumes transported or mixed down from aloft to the observation sites. In the case of the morning events, the short time lag between the strong traffic emissions and the start of NPF before 09:30 LT indicates that the morning NPF may have been facilitated by the precursor nucleating/condensable vapors from traffic emissions.

\subsection{Case studies of particle shrinkage events}

Particle shrinkage events were identified during five out of the 14 NPF events. Two shrinkage events were observed at the urban site, two at the downwind site and one at the coastal site. In the following, we present two examples of particle shrinkage, one where the $D_{\text {mode }}$ and $N_{10-25}$ were positively correlated and the other negatively correlated. The evolution of particle number size distributions during the remaining three events can be found in Fig. A3.

On the 12 August 2010 at the urban site in the warm season, the start of morning NPF occurred at $\sim 08: 00 \mathrm{LT}$ in the midst of traffic rush hours (Fig. 5). It was then immediately followed by intense particle growth from 11 to $51 \mathrm{~nm}$ until 12:30 LT. The maximum $N_{10-25}$ of $5.2 \times 10^{4} \mathrm{~cm}^{-3}$ at 10:00 LT was preceded by a local minimum CS of $1.7 \times 10^{-2} \mathrm{~s}^{-1}$, and it was correlated with a $\mathrm{SO}_{2}$ peak of $3.6 \mathrm{ppb}$. The median $J_{1}$ and GRPARGAN were $216 \mathrm{~cm}^{-2} \mathrm{~s}^{-1}$ and $7.4 \mathrm{~nm} \mathrm{~h}^{-1}$, respectively. Between 12:30 and 16:00 LT, the $D_{\text {mode }}$ and CS decreased from 32 to $11 \mathrm{~nm}$ and $3.1 \times 10^{-2}$ to $1.5 \times 10^{-2} \mathrm{~s}^{-1}$, respectively. It is notable that the shrinkage occurred during periods with the strongest atmospheric dilution (max. mixing height $590 \mathrm{~m}$ ), highest ambient temperature $\left(\max .34^{\circ} \mathrm{C}\right)$ and lowest relative humidity (min. $61 \%$ ). The continuous decrease of CS as well as CO and $\mathrm{NO}_{\mathrm{x}}$ during the shrinkage period suggests that the site was not impacted by local primary emissions. Meanwhile, the $N_{10-25}$ and $\mathrm{SO}_{2}$ were increasing with time. The $N_{10-25}$ reached another maximum of $5.1 \times 10^{4} \mathrm{~cm}^{-3}$ near the end of the shrinkage. The $\mathrm{GR}_{\mathrm{MOD}}$ during the growth and shrinkage were 11 and $-5.6 \mathrm{~nm} \mathrm{~h}^{-1}$, respectively. The winds of below $1.7 \mathrm{~m} \mathrm{~s}^{-1}$ were mild throughout the day. The winds were from the south before 12:00 LT, but then changed to westerly during the shrinkage period. The change of wind direction was accompanied with a slight increase of wind speed and the appearance of cloud clover, as indicated by the sudden drop of UVI at 14:00 LT. The maximum $\mathrm{O}_{3}$ was $51 \mathrm{ppb}$. The $\mathrm{SO}_{2}$ peak of $3.4 \mathrm{ppb}$ during the shrinkage period was of particular interest as the rise of $\mathrm{SO}_{2}$ levels was simultaneously observed at three other air quality monitoring sites 

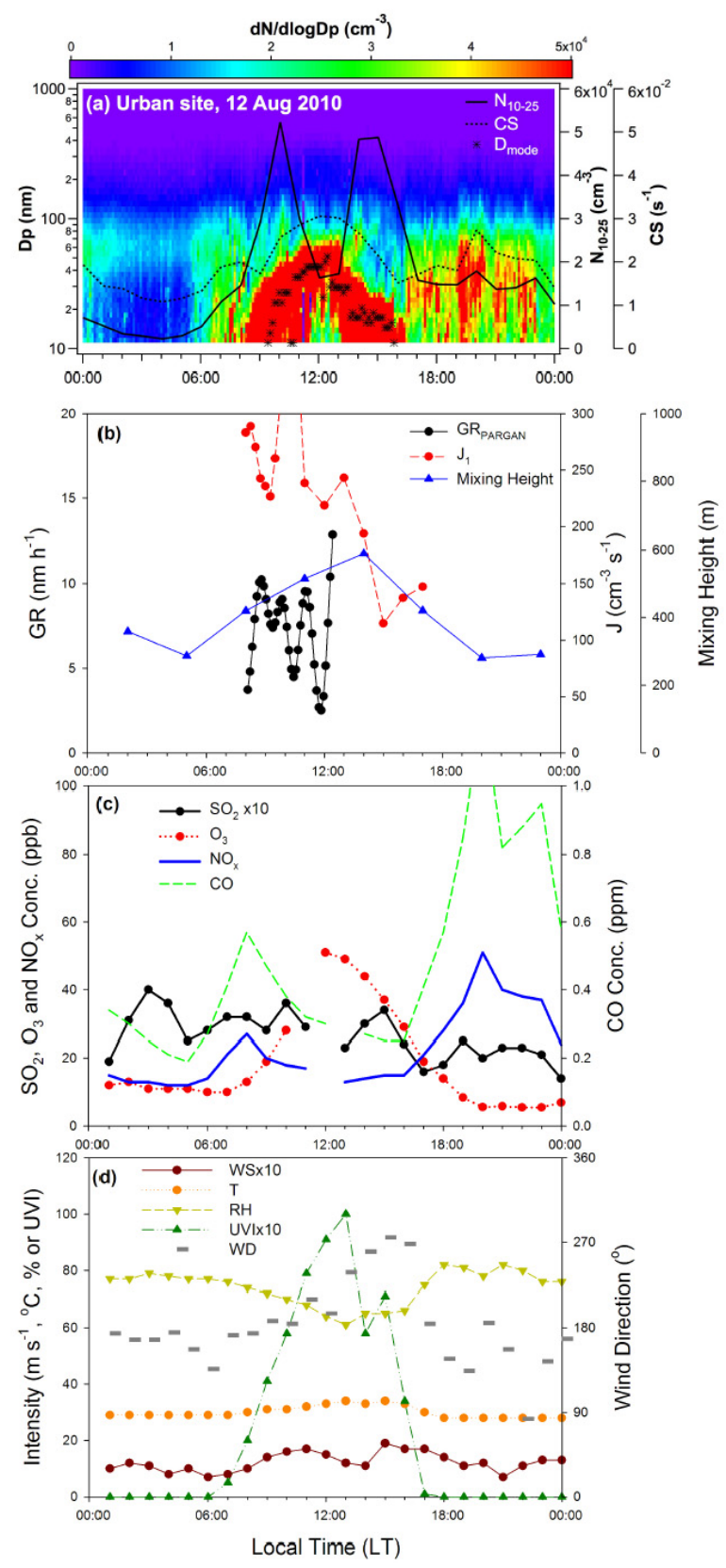

Fig. 5. The same as Fig. 3, except this is for a NPF, growth and shrinkage event on the 12 August 2010.

near the urban basin (Fig. A4). These results suggest that the $\mathrm{SO}_{2}$-enriched and low-CS air mass due to atmospheric advection and mixing may in turn have caused another NPF event near the end of particle shrinkage period, while the enhanced atmospheric dilution and hot/dry ambient conditions favor the evaporation of semi-volatile species from the particles to the gas phase. The former explains the increasing $N_{10-25}$ whereas the latter results in the decreasing $D_{\text {mode }}$.

On the 3 January 2009 at the coastal site in the cold season, the midday NPF between 10:30 and 13:00 LT was fol-
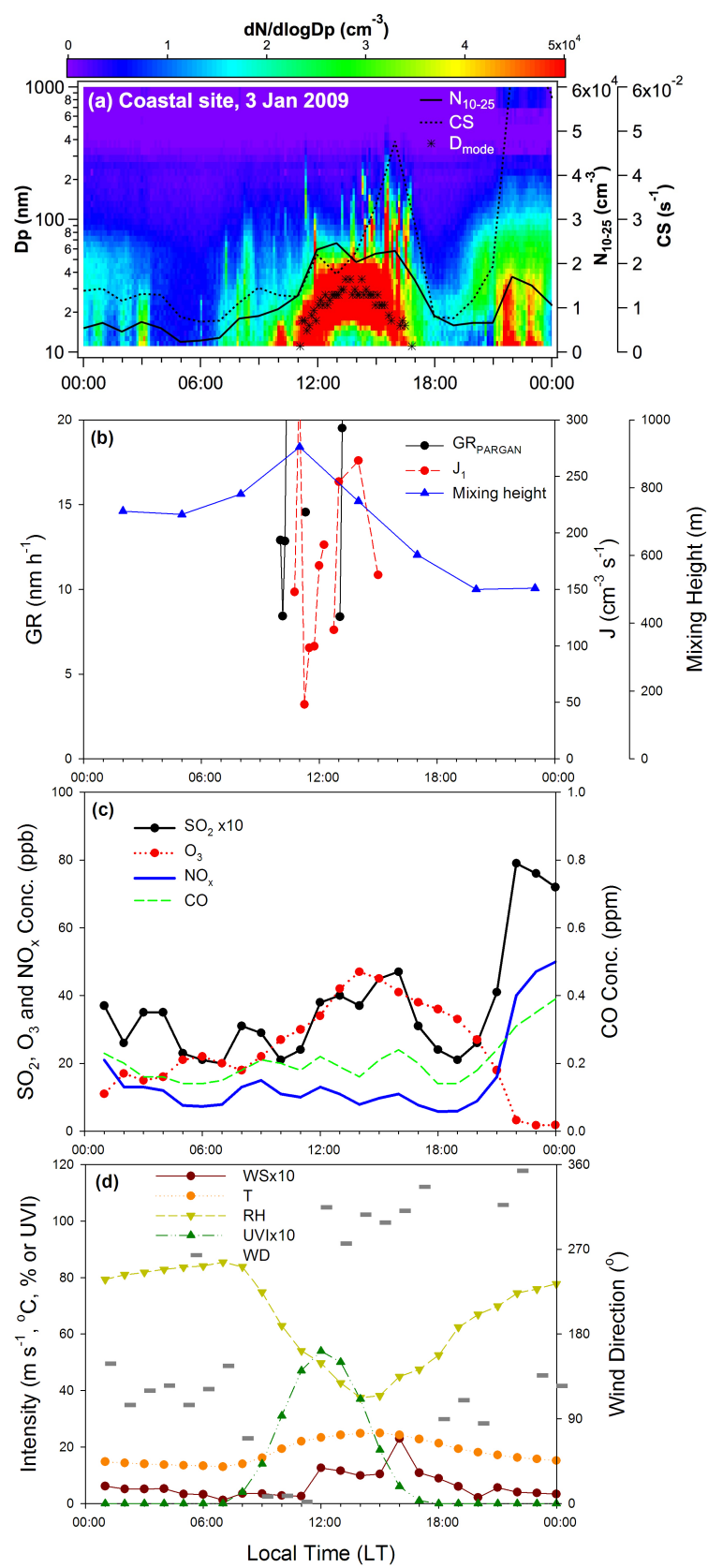

Fig. 6. The same as Fig. 3, except this is for a NPF, growth and shrinkage event on the 3 January 2009.

lowed by intense particle shrinkage (Fig. 6). At the start of NPF, the $N_{10-25}$ increased rapidly from $1.0 \times 10^{4} \mathrm{~cm}^{-3}$ to $2.5 \times 10^{4} \mathrm{~cm}^{-3}$. The $\mathrm{SO}_{2}$ also increased from 2.1 to $4.0 \mathrm{ppb}$. Afterwards, the particles grew from 11 to $36 \mathrm{~nm}$. The median $J_{1}$ and GR PARGAN were $99 \mathrm{~cm}^{-2} \mathrm{~s}^{-1}$ and $15 \mathrm{~nm} \mathrm{~h}^{-1}$, respectively. Then the $N_{10-25}$ gradually decreased to $0.6 \times 10^{4} \mathrm{~cm}^{-3}$ by 19:00 LT and the $D_{\text {mode }}$ decreased from 30 to $11 \mathrm{~nm}$ between 14:00 and 17:00 LT. The GR $\mathrm{MOD}_{\mathrm{D}}$ during the growth and shrinkage were 7.8 and $-5.1 \mathrm{~nm} \mathrm{~h}^{-1}$, respectively. The elevated $\mathrm{CS}, \mathrm{SO}_{2}, \mathrm{CO}$ and 
$\mathrm{NO}_{\mathrm{x}}$ at 16:00 LT indicate an impact of polluted air. However, it did not affect the apparent particle shrinkage. Although not measured on-site, a nearby monitoring site $(8.3 \mathrm{~km}$ to the southeast) shows that it was a cloudless, sunny day with the maximum UVI of 4.1 between 12:00 and 13:00 LT. The maximum $\mathrm{O}_{3}$ was $47 \mathrm{ppb}$. The prevailing north-northeasterly winds were strong $\left(>4 \mathrm{~m} \mathrm{~s}^{-1}\right)$, cool and stable throughout the event day. It is also notable that the temperature increased from a minimum $12^{\circ} \mathrm{C}$ to a maximum $20^{\circ} \mathrm{C}$ between 12:00 and 16:00 LT. These results suggest that the strong dilution due to elevated wind speed and the large temperature rise were likely the driving forces leading to the evaporation of semi-volatile species from the particles to the gas phase. However, unlike the previous example, the above particle shrinkage is characterized by a simultaneous decrease of $D_{\text {mode }}$ and $N_{10-25}$.

The above observations clearly show that new particle growth can be a reversible process under certain atmospheric conditions. For example, enhanced dilution and hot/dry ambient conditions can decrease the ambient vapor partial pressure or increase the equilibrium vapor pressure over the particle surface. As such, the condensed vapors tend to evaporate off the particle phase. At present it is unclear what were the evaporating vapors involved during the particle shrinkage. Potential candidates include semi-volatile ammonium nitrate $\left(\mathrm{NH}_{4} \mathrm{NO}_{3}\right)$ and organics compounds due to their high volatility and abundance in ambient air. In central Taiwan, Fang et al. (2006) showed that the major ionic species in ultrafine particles are $\mathrm{SO}_{4}^{2-}$, followed by $\mathrm{NH}_{4}^{+}$and $\mathrm{NO}_{3}^{-}$. Furthermore, Lin et al. (2006) reported the annual average of $\mathrm{NH}_{3}$ was $12.3 \mathrm{ppb}$, with the highest average of $16.4 \mathrm{ppb}$ observed in the summer. More recently, Bzdek et al. (2012) showed that $29-46 \%$ of the total mass growth of new particles were attributable to $\mathrm{SO}_{4}^{2-}$ at an urban site in Wilmington, DE, USA. The remaining, more than $50 \%$, new particle growth was due to $\mathrm{NO}_{3}^{-}, \mathrm{NH}_{4}^{+}$and organics. In addition, Riipinen et al. (2012) suggested that the reversible net condensation of gas-phase oxidation products is an important process governing organic vapor uptake by nanoparticles. The above studies demonstrate the potentially abundant and semi-volatile $\mathrm{NH}_{4}^{+}$, $\mathrm{NO}_{3}^{-}$and organics in the particle phase, and thus we speculate that they may have been involved in the particle shrinkage in the present study.

\section{Conclusions}

This study provides the first systematic analysis for new particle formation (NPF) and growth events at four distinct types of environment (urban, coastal, mountain and downwind) in an air quality management district of subtropical central Taiwan. A total of 14 NPF and growth events were identified from October 2008 to January 2009 (cold period) and from August 2010 to October 2010 (warm period). The events were then analyzed for aerosol dynamics and properties, air pollutant and meteorological conditions. Some NPF events were more or less limited to morning hours, whereas others occurred during midday hours. In either cases, the onset of NPF events coincided with decreases of CS and increases of $\mathrm{SO}_{2}$ during periods (09:00-13:00 LT) under enhanced atmospheric mixing and dilution. The increase of $\mathrm{SO}_{2}$ during enhanced dilution, in particular, suggests that the $\mathrm{SO}_{2}$ was not from local traffic emissions but likely from power plant or industrial plumes transported or mixed down from aloft to the observation sites. Nevertheless, the lower or comparable $\mathrm{SO}_{2}$ on event days than on non-event days suggests that $\mathrm{SO}_{2}$ was not a limiting factor for NPF.

Overall, the NPF events contributed significantly to the ambient ultrafine particles, with the maximum concentrations of $2.5-8.9 \times 10^{4} \mathrm{~cm}^{-3}$, which were 2-4 times higher than that due to typical traffic emissions. The approximationderived particle formation rate $J_{10}$ and growth rates $\mathrm{GR}_{\mathrm{MOD}}$ were in the range of $4.4-30 \mathrm{~cm}^{-3} \mathrm{~s}^{-1}$ and $7.4-24 \mathrm{~nm} \mathrm{~h}^{-1}$, respectively. The nucleation rates $J_{1}$ and growth rates GRPARGAN inverted from the measured aerosol size distributions were in the range of $40-253 \mathrm{~cm}^{-3} \mathrm{~s}^{-1}$ and $6.5-$ $15 \mathrm{~nm} \mathrm{~h}^{-1}$, respectively.

A unique feature of our observations is the particle shrinkage following their prior formation and growth. In the five shrinkage events, their respective $\mathrm{GR}_{\mathrm{MOD}}$ ranged from -5.1 to $-7.6 \mathrm{~nm} \mathrm{~h}^{-1}$. The shrinking and corresponding particle volume losses indicate that a notable fraction of the originally condensed chemical species was semi-volatile and had evaporated from the particle phase to the gas phase under atmospheric conditions. In intense cases where particles shrank back to the smallest measurable size of $\sim 10 \mathrm{~nm}$, the new particle growth and shrinkage thereby created a unique "arch-like" shape in the size distribution contour plot. Timeseries analyses of air pollutants and meteorological conditions indicate that the particle shrinkage was related to air masses with enhanced atmospheric dilution, high ambient temperature and low relative humidity. Such atmospheric conditions favor the evaporation of semi-volatile species from the particle phase to the gas phase. Although chemical identification of the potential evaporating vapors was not possible in the present study, we speculate that the candidate vapors can be $\mathrm{NH}_{4}^{+}, \mathrm{NO}_{3}^{-}$and organics due to their semi-volatile nature and abundance in the study area. Chemical and volatility analysis of the nucleating and condensing/evaporating vapors is required in the future to infer more definitive mechanisms of NPF, particle growth and shrinkage that are relevant to climate change and public health.

\section{Appendix A}

\section{A1 Eight consecutive morning NPF events with two particle shrinkage events}

Figure A1 shows the diurnal variations of the number size distributions during eight consecutive morning NPF events 


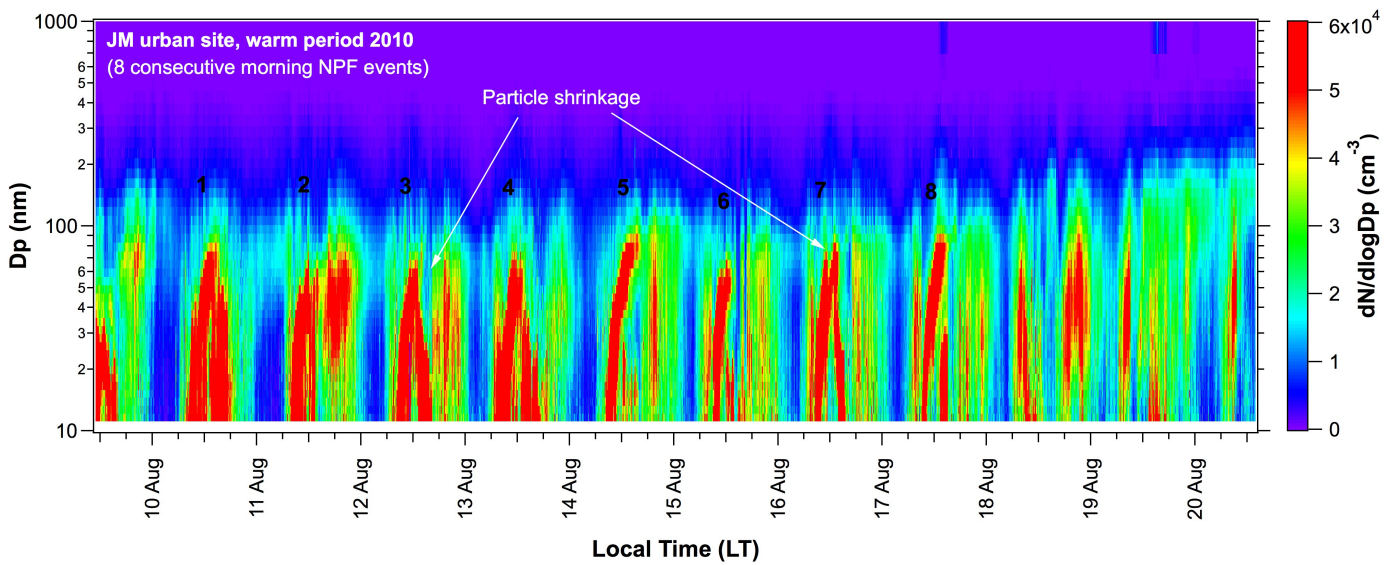

Fig. A1. The measured particle number size distributions during eight consecutive NPF events at the urban site from the 10 to the 17 August 2010. Among them there were two particle shrinkage events on the 12 and the 16 August 2010.
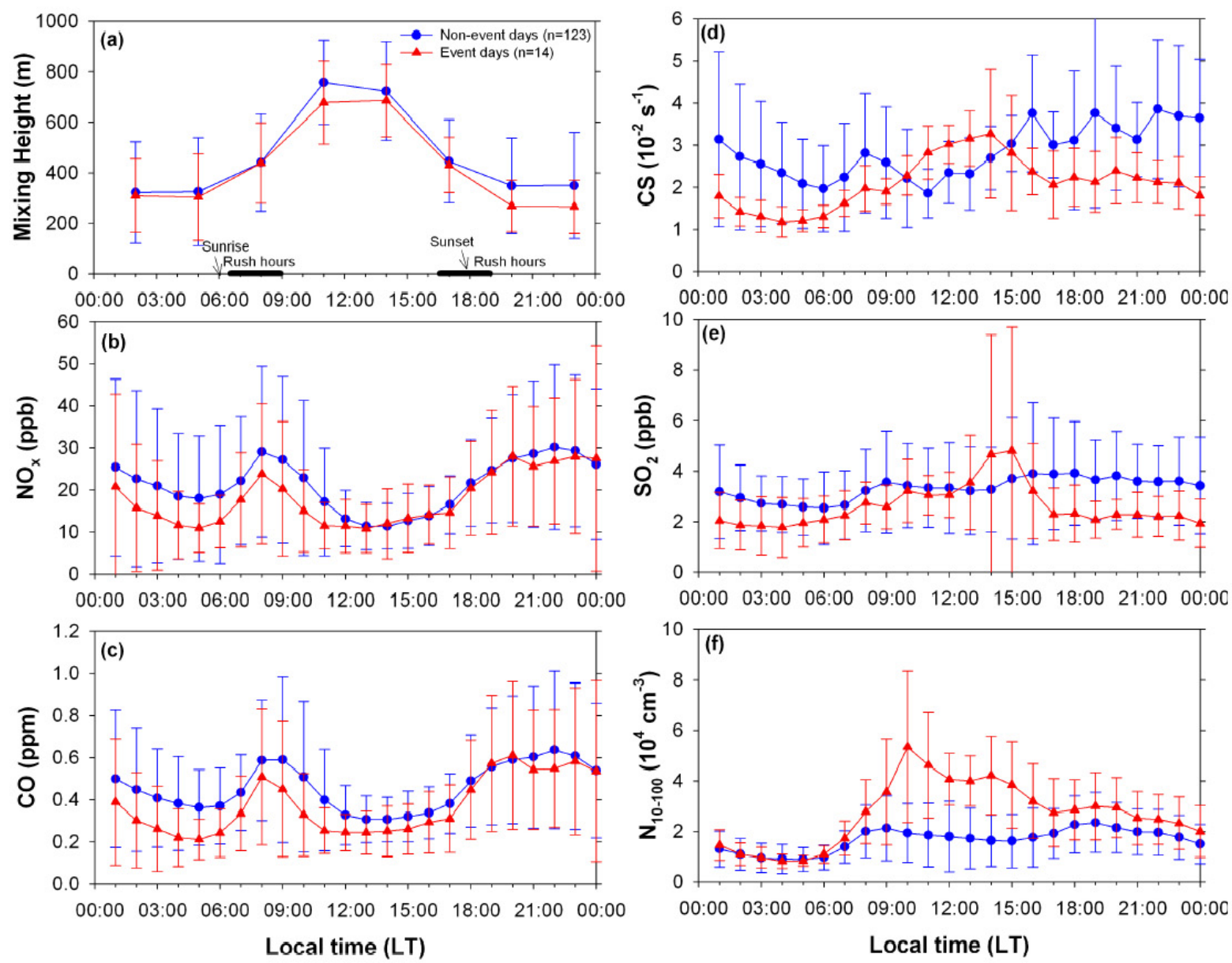

Fig. A2. Diurnal variations of the average (a) mixing height, (b) $\mathrm{NO}_{\mathrm{x}}$, (c) $\mathrm{CO}$, (d) condensation sink (CS), (e) $\mathrm{SO}_{2}$ and (f) $10-100 \mathrm{~nm}$ particle number $\left(N_{10-100}\right)$ concentrations on non-event and event days. 

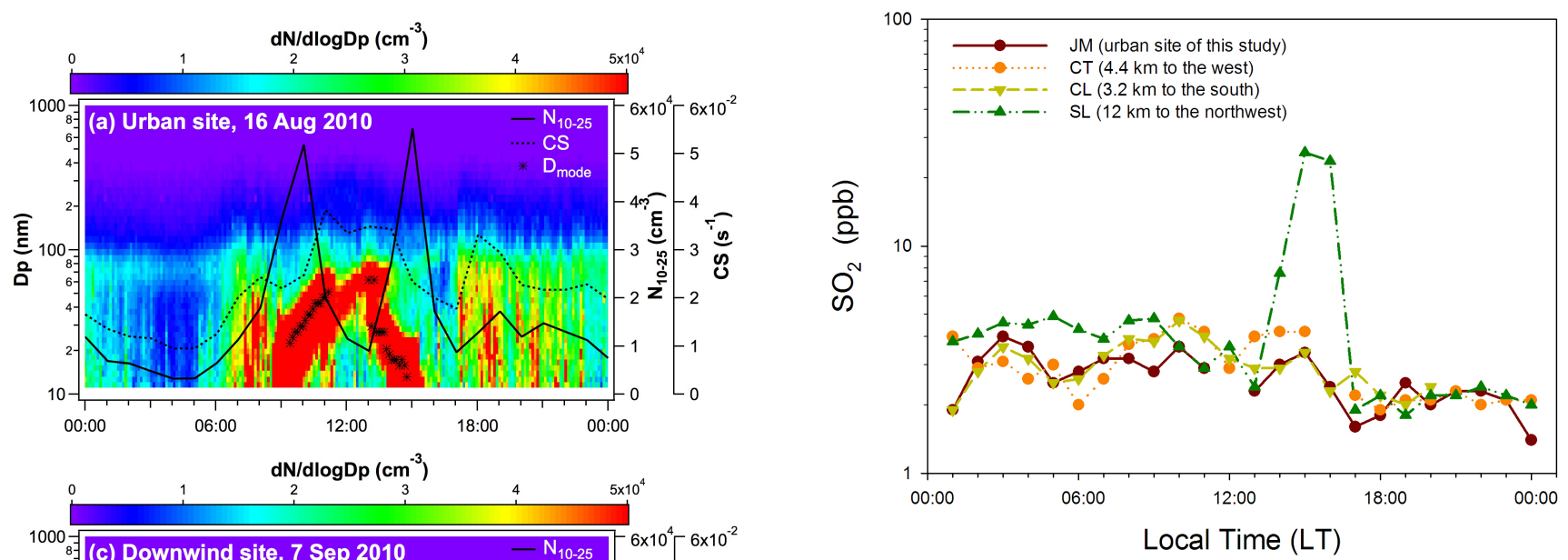

Fig. A2. Diurnal variations of $\mathrm{SO}_{2}$ measured at the urban site (JM) and three nearby air quality monitoring sites (CT, CL and SL) on the 12 August 2010.

concentrations on non-event and event days. As shown, the differences of hourly pollutant levels and mixing height between the non-event and event days were not statistically significance. Nevertheless, the diurnal trends of the hourlyaverage CS and $N_{10-100}$ on events days deviated away from those on non-event days during late morning hours, between 09:00-12:00 LT. On event days, the $2 \mathrm{~h}$ lag between the $\mathrm{NO}_{\mathrm{x}}$ and CO peaks at 08:00 LT and the $N_{10-100}$ peak at 10:00 LT suggests that the elevated ultrafine particles was not emitted directly from motor vehicles but formed shortly afterwards in the atmosphere, i.e., via NPF. On non-events days, the diurnal variations of $N_{10-100}$ were nearly identical to those of $\mathrm{NO}_{\mathrm{x}}$ and $\mathrm{CO}$, indicating strong influence from traffic emissions.

Fig. A1. The measured particle number size distributions, $D_{\text {mode }}$ (stars), $N_{10-25}$ (solid lines) and CS (dash lines) during the three other particle shrinkage events on the (a) 16 August, 2010, (b) 5 September 2010 and (c) 7 September 2010.

at the urban site from the 10 to the 17 August 2010. Among them there were two particle shrinkage events on the 12 and the 16 August 2010. As shown, the particles initially grew to sizes of 50-60 nm and then shrank back to the smallest measurable sizes of $\sim 10 \mathrm{~nm}$, creating a unique "arch-like" shape in the contour plot.

A2 Diurnal variations of mixing height, air pollutants, condensation sink and ultrafine particle number on non-event and event days

Figure $\mathrm{A} 2$ presents the diurnal variations of the average mixing height, air pollutants $\left(\mathrm{NO}_{\mathrm{x}}, \mathrm{CO}, \mathrm{SO}_{2}\right)$, condensation sink (CS), and $10-100 \mathrm{~nm}$ ultrafine particle number $\left(N_{10-100}\right)$

\section{A3 Three other particle shrinkage events}

Figure A3 shows the measured number size distributions, $D_{\text {mode }}, N_{10-25}$ and CS during the three other particle shrinkage events on the (a) 16 August 2010, (b) 5 September 2010 and (c) 7 September 2010. As shown, the grown particles in the first event (a) shrank back to the smallest measurable particle size of $\sim 10 \mathrm{~nm}$, whereas in the remaining two events (b and c) they shrank back to sizes of $\sim 20 \mathrm{~nm}$ and then stopped. The $N_{10-25}$ during the first and third events were increasing with time, whereas during the second event they were decreasing with time.

\section{A4 Regional-scale $\mathrm{SO}_{2}$ impact}

Figure A4 shows the diurnal variations of $\mathrm{SO}_{2}$ at the present urban site (JM) and three nearby air quality monitoring sites on the 12 August 2010. As shown, the rise of $\mathrm{SO}_{2}$ was simultaneously observed at three other air quality monitoring sites 
near the urban basin, suggesting regional-scale $\mathrm{SO}_{2}$ impact occurred at 15:00 LT.

Acknowledgements. The authors wish to express their appreciation to the Editor V.-M. Kerminen and anonymous referees for their helpful comments, and the Taiwan EPA for making the air quality monitoring sites available for the present study. The financial support from the Taiwan National Science Council (NSC972218-E-039-002-MY3 and NSC100-2628-E-039-001-MY3) and the China Medical University (CMU98-N1-26) are gratefully acknowledged.

The service charges for this open access publication have been covered by the Max Planck Society.

Edited by: V.-M. Kerminen

\section{References}

Anttila, T., Kerminen, V.-M., and Lehtinen, K. E. J.: Parameterizing the formation rate of new particles The effect of nuclei selfcoagulation, J. Aerosol Sci., 41, 621-636, 2010.

Atkinson, R. W., Fuller, G. W., Anderson, H. R., Harrison, R. M., and Armstrong, B.: Urban ambient particle metrics and health, Epidemiology, 21, 501-511, 2010.

Backman, J., Rizzo, L. V., Hakala, J., Nieminen, T., Manninen, H. E., Morais, F., Aalto, P. P., Siivola, E., Carbone, S., Hillamo, R., Artaxo, P., Virkkula, A., Petäjä, T., and Kulmala, M.: On the diurnal cycle of urban aerosols, black carbon and the occurrence of new particle formation events in springtime $\mathrm{S}$ ao Paulo, Brazil, Atmos. Chem. Phys., 12, 11733-11751, doi:10.5194/acp12-11733-2012, 2012.

Baron, P. A, and Willeke. K.: Aerosol Measurement: Principles, Techniques, and Applications, 2nd Edn., John Wiley and Sons, New York, 2001.

Benson, D. R., Yu, J. H., Markovich, A., and Lee, S.-H.: Ternary homogeneous nucleation of $\mathrm{H}_{2} \mathrm{SO}_{4}, \mathrm{NH}_{3}$, and $\mathrm{H}_{2} \mathrm{O}$ under conditions relevant to the lower troposphere, Atmos. Chem. Phys., 11, 4755-4766, doi:10.5194/acp-11-4755-2011, 2011.

Boy, M. and Kulmala, M.: Nucleation events in the continental boundary layer: Influence of physical and meteorological parameters, Atmos. Chem. Phys., 2, 1-16, doi:10.5194/acp-2-1-2002, 2002.

Bzdek, B. R. and Johnston, M. V.: New particle formation and growth in the troposphere, Anal. Chem., 82, 7871-7878, 2010.

Bzdek, B. R., Zordan, C. A., Pennington, M. R., Luther, G. W., III, and Johnston, M. V.: Quantitative assessment of the sulfuric acid contribution to new particle growth, Environ. Sci. Technol., 46, 4365-4373, 2012.

Dal Maso, M., Kulmala, M., Riipinen, I., Wagner, R., Hussein, T., Aalto, P. P., and Lehtinen, K. E. J.: Formation and growth of fresh atmospheric aerosols: eight years of aerosol size distribution data from SMEAR II, Hyytiälä, Finland, Boreal Environ. Res., 10, 323-336, 2005.

Dusek, U., Frank, G., Hildebrandt, L., Curtius, J., Schneider, J., Walter, S., Chand, D., Drewnick, F., Hings, S., and Jung, D.: Size matters more than chemistry for cloud-nucleating ability of aerosol particles, Science, 312, 1375-1378, 2006.
Erupe, M. E., Benson, D. R., Li, J., Young, L.-H., Verheggen, B., Al-Refai, M., Tahboub, O., Cunningham, V., Frimpong, F., Viggiano, A. A., and Lee, S.-H.: Correlation of aerosol nucleation rate with sulfuric acid and ammonia in Kent, Ohio: An atmospheric observation, J. Geophys. Res., 115, D23216, doi:10.1029/2010JD013942, 2010.

Erupe, M. E., Viggiano, A. A., and Lee, S.-H.: The effect of trimethylamine on atmospheric nucleation involving $\mathrm{H}_{2} \mathrm{SO}_{4}$, Atmos. Chem. Phys., 11, 4767-4775, doi:10.5194/acp-11-47672011, 2011.

Fang, G.-C., Wu, Y.-S., Chang, S.-Y., Rau, J.-Y., Huang, S.-H., and Lin, C.-K.: Characteristic study of ionic species in nano, ultrafine, fine and coarse particle size mode at a traffic sampling site, Toxicol. Ind. Health, 22, 27-37, 2006.

Fuchs, N. A. and Sutugin, A. G.: Highly Dispersed Aerosols, Pergamon, New York, USA, 1971.

Gurjar, B., Butler, T., Lawrence, M., and Lelieveld, J.: Evaluation of emissions and air quality in megacities, Atmos. Environ., 42, 1593-1606, 2008.

Hallar, A., Lowenthal, D. H., Chirokova, G., Borys, R. D., and Wiedinmyer, C.: Persistent daily new particle formation at a mountain-top location, Atmos. Environ., 45, 4111-4115, 2011.

Hegg, D. A. and Baker, M. B.: Nucleation in the atmosphere, Rep. Prog. Phys., 72, 056801, doi:10.1088/0034-4885/72/5/056801, 2009.

Heikkilä, J., Virtanen, A., Rönkkö, T., Keskinen, J., Aakko-Saksa, P., and Murtonen, T.: Nanoparticle emissions from a heavy-duty engine running on alternative diesel fuels, Environ. Sci. Technol., 43, 9501-9506, 2009.

Heim, M., Kasper, G., Reischl, G. P., and Gerhart, C.: Performance of a new commercial electrical mobility spectrometer, Aerosol Sci. Technol., 38, 3-14, 2004.

Holmes, N. S.: A review of particle formation events and growth in the atmosphere in the various environments and discussion of mechanistic implications, Atmos. Environ., 41, 2183-2201, 2007.

Iida, K., Stolzenburg, M. R., McMurry, P. H., and Smith, J. N.: Estimating nanoparticle growth rates from size-dependent charged fractions: Analysis of new particle formation events in Mexico City, J. Geophys. Res., 113, D05207, doi:10.1088/00344885/72/5/056801, 2008.

Jacobson, M. Z., Kittelson, D. B., and Watts, W. F.: Enhanced coagulation due to evaporation and its effect on nanoparticle evolution, Environ. Sci. Technol., 39, 9486-9492, 2005.

Kanawade, V. P., Benson, D. R., and Lee, S.-H.: Statistical analysis of 4-year observations of aerosol sizes in a semi-rural continental environment, Atmos. Environ., 59, 30-38, 2012.

Kerminen, V.-M., Petäjä, T., Manninen, H. E., Paasonen, P., Nieminen, T., Sipilä, M., Junninen, H., Ehn, M., Gagné, S., Laakso, L., Riipinen, I., Vehkamäki, H., Kurten, T., Ortega, I. K., Dal Maso, M., Brus, D., Hyvärinen, A., Lihavainen, H., Leppä, J., Lehtinen, K. E. J., Mirme, A., Mirme, S., Hõrrak, U., Berndt, T., Stratmann, F., Birmili, W., Wiedensohler, A., Metzger, A., Dommen, J., Baltensperger, U., Kiendler-Scharr, A., Mentel, T. F., Wildt, J., Winkler, P. M., Wagner, P. E., Petzold, A., Minikin, A., Plass-Dülmer, C., Pöschl, U., Laaksonen, A., and Kulmala, M.: Atmospheric nucleation: highlights of the EUCAARI project and future directions, Atmos. Chem. Phys., 10, 10829-10848, doi:10.5194/acp-10-10829-2010, 2010. 
Korhonen, H., Sihto, S.-L., Kerminen, V.-M., and Lehtinen, K. E. J.: Evaluation of the accuracy of analysis tools for atmospheric new particle formation, Atmos. Chem. Phys., 11, 3051-3066, doi:10.5194/acp-11-3051-2011, 2011.

Kroll, J. H., Ng, N. L., Murphy, S. M., Flagan, R. C., and Seinfeld, J. H.: Secondary organic aerosol formation from isoprene photooxidation, Environ. Sci. Technol., 40, 1869-1877, 2006.

Kuang, C., McMurry, P. H., McCormick, A. V., and Eisele, F. L.: Dependence of nucleation rates on sulfuric acid vapor concentration in diverse atmospheric locations, J. Geophys. Res., 113, D10209, doi:10.1029/2007JD009253, 2008.

Kulmala, M. and Kerminen, V.-M.: On the formation and growth of atmospheric nanoparticles, Atmos. Res., 90, 132-150, 2008.

Kulmala, M., Dal Maso, M., Mäkelä, J., Pirjola, L., Väkevä, M., Aalto, P., Miikkulainen, P., Hämeri, K., and O'Dowd, C. D.: On the formation, growth and composition of nucleation mode particles, Tellus B, 53, 479-490, 2001.

Kulmala, M., Vehkamäki, H., Petäjä, T., Dal Maso, M., Lauri, A., Kerminen, V.-M., Birmili, W., and McMurry, P. H.: Formation and growth rates of ultrafine atmospheric particles: a review of observations, J. Aerosol Sci., 35, 143-176, 2004.

Kulmala, M., Petäjä, T., Mönkkönen, P., Koponen, I. K., Dal Maso, M., Aalto, P. P., Lehtinen, K. E. J., and Kerminen, V.-M.: On the growth of nucleation mode particles: source rates of condensable vapor in polluted and clean environments, Atmos. Chem. Phys., 5, 409-416, doi:10.5194/acp-5-409-2005, 2005.

Kulmala, M., Petäjä, T., Nieminen, T., Sipilä, M., Manninen, H. E., Lehtipalo, K., Dal Maso, M., Aalto, P. P., Junninen, H., Paasonen, P., Riipinen, I., Lehtinen, K. E. J., Laaksonen, A., and Kerminen, V.-M.: Measurement of the nucleation of atmospheric aerosol particles, Nat. Protoc., 7, 1651-1667, 2012.

Laaksonen, A., Kulmala, M., O’Dowd, C. D., Joutsensaari, J., Vaattovaara, P., Mikkonen, S., Lehtinen, K. E. J., Sogacheva, L., Dal Maso, M., Aalto, P., Petäjä, T., Sogachev, A., Yoon, Y. J., Lihavainen, H., Nilsson, D., Facchini, M. C., Cavalli, F., Fuzzi, S., Hoffmann, T., Arnold, F., Hanke, M., Sellegri, K., Umann, B., Junkermann, W., Coe, H., Allan, J. D., Alfarra, M. R., Worsnop, D. R., Riekkola, M.-L., Hyötyläinen, T., and Viisanen, Y.: The role of VOC oxidation products in continental new particle formation, Atmos. Chem. Phys., 8, 2657-2665, doi:10.5194/acp-82657-2008, 2008.

Lehtinen, K. E. J., Dal Maso, M., Kulmala, M., and Kerminen, V.M.: Estimating nucleation rates from apparent particle formation rates and vice versa: Revised formulation of the KerminenKulmala equation, J. Aerosol Sci., 38, 988-994, 2007.

Lin, Y. C., Cheng, M. T., Ting, W. Y., and Yeh, C. R.: Characteristics of gaseous $\mathrm{HNO}_{2}, \mathrm{HNO}_{3}, \mathrm{NH}_{3}$ and particulate ammonium nitrate in an urban city of Central Taiwan, Atmos. Environ., 40, 4725-4733, 2006.

Lyman, W. J., Reehl, W. F., and Rosenblatt, D. H.: Handbook of Chemical Property Estimation Methods, American Chemical Society, Washington DC, USA, 1990.

Merikanto, J., Spracklen, D. V., Mann, G. W., Pickering, S. J., and Carslaw, K. S.: Impact of nucleation on global CCN, Atmos. Chem. Phys., 9, 8601-8616, doi:10.5194/acp-9-8601-2009, 2009.

Metzger, A., Verheggen, B., Dommen, J., Duplissy, J., Prevot, A. S. H., Weingartner, E., Riipinen, I., Kulmala, M., Spracklen, D. V., and Carslaw, K. S.: Evidence for the role of organics in aerosol particle formation under atmospheric conditions, Proc. Nat. Acad. Sci. USA, 107, 6646-6651, 2010.

Molina, M. J.: Atmospheric evolution of organic aerosol, Geophys. Res. Lett., 31, L22104, doi:10.1029/2004GL020910, 2004.

Morawska, L., Ristovski, Z., Jayaratne, E. R., Keogh, D. U., and Ling, X.: Ambient nano and ultrafine particles from motor vehicle emissions: Characteristics, ambient processing and implications on human exposure, Atmos. Environ., 42, 8113-8138, 2008.

Mönkkönen, P., Koponen, I. K., Lehtinen, K. E. J., Hämeri, K., Uma, R., and Kulmala, M.: Measurements in a highly polluted Asian mega city: observations of aerosol number size distribution, modal parameters and nucleation events, Atmos. Chem. Phys., 5, 57-66, doi:10.5194/acp-5-57-2005, 2005.

Nel, A.: Toxic potential of materials at the nanolevel, Science, 311 , 622-627, 2006.

Peng, R. D., Bell, M. L., Geyh, A. S., McDermott, A., Zeger, S. L., Samet, J. M., and Dominici, F.: Emergency admissions for cardiovascular and respiratory diseases and the chemical composition of fine particle air pollution, Environ. Health Perspect. 117, 957-963, 2009.

Petäjä, T., Mauldin, III, R. L., Kosciuch, E., McGrath, J., Nieminen, T., Paasonen, P., Boy, M., Adamov, A., Kotiaho, T., and Kulmala, M.: Sulfuric acid and $\mathrm{OH}$ concentrations in a boreal forest site, Atmos. Chem. Phys., 9, 7435-7448, doi:10.5194/acp9-7435-2009, 2009.

Pierce, J. R., Leaitch, W. R., Liggio, J., Westervelt, D. M., Wainwright, C. D., Abbatt, J. P. D., Ahlm, L., Al-Basheer, W., Cziczo, D. J., Hayden, K. L., Lee, A. K. Y., Li, S.-M., Russell, L. M., Sjostedt, S. J., Strawbridge, K. B., Travis, M., Vlasenko, A., Wentzell, J. J. B., Wiebe, H. A., Wong, J. P. S., and Macdonald, A. M.: Nucleation and condensational growth to CCN sizes during a sustained pristine biogenic SOA event in a forested mountain valley, Atmos. Chem. Phys., 12, 3147-3163, doi:10.5194/acp-12-3147-2012, 2012.

Pirjola, L., O'Dowd, C. D., and Kulmala, M.: A model prediction of the yield of cloud condensation nuclei from coastal nucleation events, J. Geophys. Res., 107, 8098, doi:10.1029/2000JD000213, 2002.

Pope, C. A., III, Ezzati, M., and Dockery, D. W.: Fine-particulate air pollution and life expectancy in the United States, New Engl. J. Med., 360, 376-386, 2009.

Raga, G., Baumgardner, D., Castro, T., Martinez-Arroyo, A., and Navarro-González, R.: Mexico City air quality: A qualitative review of gas and aerosol measurements (1960-2000), Atmos. Environ., 35, 4041-4058, 2001.

Reischl, G. P.: Measurement of ambient aerosols by the differential mobility analyzer method: Concepts and realization criteria for the size range between 2 and $500 \mathrm{~nm}$, Aerosol Sci. Technol., 14, 5-24, 1991.

Riipinen, I., Sihto, S.-L., Kulmala, M., Arnold, F., Dal Maso, M., Birmili, W., Saarnio, K., Teinilä, K., Kerminen, V.-M., Laaksonen, A., and Lehtinen, K. E. J.: Connections between atmospheric sulphuric acid and new particle formation during QUEST III-IV campaigns in Heidelberg and Hyytiälä, Atmos. Chem. Phys., 7, 1899-1914, doi:10.5194/acp-7-1899-2007, 2007.

Riipinen, I., Pierce, J. R., Yli-Juuti, T., Nieminen, T., Häkkinen, S., Ehn, M., Junninen, H., Lehtipalo, K., Petaja, T., Slowik, J., Chang, R., Shantz, N. C., Abbatt, J., Leaitch, W. R., Kerminen, 
V.-M., Worsnop, D. R., Pandis, S. N., Donahue, N. M., and Kulmala, M.: Organic condensation: A vital link connecting aerosol formation to cloud condensation nuclei $(\mathrm{CCN})$ concentrations, Atmos. Chem. Phys., 11, 3865-3878, 2011, http://www.atmos-chem-phys.net/11/3865/2011/.

Riipinen, I., Yli-Juuti, T., Pierce, J. R., Petäjä, T., Worsnop, D. R., Kulmala, M., and Donahue, N. M.: The contribution of organics to atmospheric nanoparticle growth, Nature Geosci., 5, 453-458, doi:10.1038/NGEO1499, 2012.

Salma, I., Borsós, T., Weidinger, T., Aalto, P., Hussein, T., Dal Maso, M., and Kulmala, M.: Production, growth and properties of ultrafine atmospheric aerosol particles in an urban environment, Atmos. Chem. Phys., 11, 1339-1353, doi:10.5194/acp-111339-2011, 2011.

Seinfeld, J. H. and Pandis, S. N.: Atmospheric Chemistry and Physics, 2nd Edn., John Wiley and Sons, New York, 2006.

Shen, X. J., Sun, J. Y., Zhang, Y. M., Wehner, B., Nowak, A., Tuch, T., Zhang, X. C., Wang, T. T., Zhou, H. G., Zhang, X. L., Dong, F., Birmili, W., and Wiedensohler, A.: First long-term study of particle number size distributions and new particle formation events of regional aerosol in the North China Plain, Atmos. Chem. Phys., 11, 1565-1580, doi:10.5194/acp-11-15652011, 2011.

Sipila, M., Berndt, T., Petäjä, T., Brus, D., Vanhanen, J., Stratmann, F., Patokoski, J., Mauldin, R. L., Hyvarinen, A. P., Lihavainen, H., and Kulmala, M.: The role of sulfuric acid in atmospheric nucleation, Science, 327, 1243-1246, 2010.

Smith, J. N., Barsanti, K. C., Friedli, H. R., Ehn, M., Kulmala, M., Collins, D. R., Scheckman, J. H., Williams, B. J., and McMurry, P. H.: Observations of aminium salts in atmospheric nanoparticles and possible climatic implications, Proc. Nat. Acad. Sci. USA, 107, 6634-6639, 2010.

Stanier, C. O., Khlystov, A. Y., and Pandis, S. N.: Nucleation events during the Pittsburgh Air Quality Study: Description and relation to key meteorological, gas phase, and aerosol parameters, Aerosol Sci. Technol., 38(sup1), 253-264, 2004.

Stolzenburg, M. R., McMurry, P. H., Sakurai, H., Smith, J. N., Mauldin, R. L., III, Eisele, F. L., and Clement, C. F.: Growth rates of freshly nucleated atmospheric particles in Atlanta, J. Geophys. Res., 110, D22S05, doi:10.1029/2005JD005935, 2005.

TW EPA: Air Quality Annual Report of R.O.C (Taiwan), Taiwan Environmental Protection Administration, 2009.

Vanhanen, J., Mikkilä, J., Lehtipalo, K., Sipila, M., Manninen, H. E., Siivola, E., Petäjä, T., and Kulmala, M.: Particle size magnifier for nano-CN detection, Aerosol Sci. Technol., 45, 533-542, 2011.

Verheggen, B. and Mozurkewich, M.: Determination of nucleation and growth rates from observation of a SO2 induced atmospheric nucleation event, J. Geophys. Res., 107, 4123, doi:10.1029/2001JD000683, 2002.
Verheggen, B. and Mozurkewich, M.: An inverse modeling procedure to determine particle growth and nucleation rates from measured aerosol size distributions, Atmos. Chem. Phys., 6, 2927 2942, doi:10.5194/acp-6-2927-2006, 2006.

Wu, Z., Hu, M., Liu, S., Wehner, B., Bauer, S., Ma Bling, A., Wiedensohler, A., Petäjä, T., Dal Maso, M., and Kulmala, M.: New particle formation in Beijing, China: Statistical analysis of a 1-year data set, J. Geophys. Res., 112, D09209, doi:10.1029/2006JD007406, 2007.

Yao, X., Choi, M. Y., Lau, N. T., Lau, A. P. S., Chan, C. K., and Fang, M.: Growth and shrinkage of new particles in the atmosphere in Hong Kong, Aerosol Sci. Technol., 44, 639-650, 2010.

Young, L.-H., Liou, Y.-J., Cheng, M.-T., Lu, J.-H., Yang, H.-H., Tsai, Y. I., Wang, L.-C., Chen, C.-B., and Lai, J.-S.: Effects of biodiesel, engine load and diesel particulate filter on nonvolatile particle number size distributions in heavy-duty diesel engine exhaust, J. Hazard. Mater., 199-200, 282-289, 2012.

Yu, H., McGraw, R., and Lee, S.-H.: Effects of amines on formation of sub-3 nm particles and their subsequent growth, Geophys. Res. Lett., 39, L02807, doi:10.1029/2011GL050099, 2012.

Yu, R. C., Teh, H. W., Jaques, P. A., Sioutas, C., and Froines, J. R.: Quality control of semi-continuous mobility size-fractionated particle number concentration data, Atmos. Environ., 38, 33413348, 2004.

Yue, D. L., Hu, M., Zhang, R. Y., Wang, Z. B., Zheng, J., Wu, Z. J., Wiedensohler, A., He, L. Y., Huang, X. F., and Zhu, T.: The roles of sulfuric acid in new particle formation and growth in the mega-city of Beijing, Atmos. Chem. Phys., 10, 4953-4960, doi:10.5194/acp-10-4953-2010, 2010.

Zanobetti, A. and Schwartz, J.: The effect of fine and coarse particulate air pollution on mortality: a national analysis, Environ. Health Perspect., 117, 898-903, 2009.

Zhang, K. M. and Wexler, A. S.: A hypothesis for growth of fresh atmospheric nuclei, J. Geophys. Res., 107, 4577, doi:10.1029/2002JD002180, 2002.

Zhang, K. M. and Wexler, A. S.: Evolution of particle number distribution near roadways - Part I: Analysis of aerosol dynamics and its implications for engine emission measurement, Atmos. Environ., 38, 6643-6653, 2004.

Zhang, R., Suh, I., Zhao, J., Zhang, D., Fortner, E. C., Tie, X., Molina, L. T., and Molina, M. J.: Atmospheric new particle formation enhanced by organic acids, Science, 304, 1487-1490, 2004.

Zhang, R., Wang, L., Khalizov, A. F., Zhao, J., Zheng, J., McGraw, R. L., and Molina, L. T.: Formation of nanoparticles of blue haze enhanced by anthropogenic pollution, Proc. Nat. Acad. Sci. USA, 106, 17650-17654, 2009.

Zhang, R., Khalizov, A., Wang, L., Hu, M. and, Xu, W.: Nucleation and growth of nanoparticles in the atmosphere, Chem. Rev., 112, 1957-2011, 2012. 